San Jose State University

SJSU ScholarWorks

Master's Theses

Master's Theses and Graduate Research

Fall 2019

\title{
Climate-Driven Insect Herbivory in Mixed Coast Live Oak Woodlands Within the Mt. Hamilton Range, Santa Clara County
}

Michelle Domocol

San Jose State University

Follow this and additional works at: https://scholarworks.sjsu.edu/etd_theses

\section{Recommended Citation}

Domocol, Michelle, "Climate-Driven Insect Herbivory in Mixed Coast Live Oak Woodlands Within the Mt. Hamilton Range, Santa Clara County" (2019). Master's Theses. 5061.

DOI: https://doi.org/10.31979/etd.xuky-txw9

https://scholarworks.sjsu.edu/etd_theses/5061

This Thesis is brought to you for free and open access by the Master's Theses and Graduate Research at SJSU ScholarWorks. It has been accepted for inclusion in Master's Theses by an authorized administrator of SJSU ScholarWorks. For more information, please contact scholarworks@sjsu.edu. 


\title{
CLIMATE-DRIVEN INSECT HERBIVORY IN MIXED COAST LIVE OAK WOODLANDS WITHIN THE MT. HAMILTON RANGE, SANTA CLARA COUNTY
}

\author{
A Thesis \\ Presented to \\ The Faculty of the Department of Environmental Studies \\ San José State University
}

\author{
In Partial Fulfillment \\ of the Requirements for the Degree \\ Master of Science
}

by

Michelle Domocol

December 2019 
(C) 2019

Michelle Domocol

ALL RIGHTS RESERVED 
The Designated Thesis Committee Approves the Thesis Titled

CLIMATE-DRIVEN INSECT HERBIVORY IN MIXED COAST LIVE OAK WOODLANDS WITHIN THE MT. HAMILTON RANGE, SANTA CLARA COUNTY

by

Michelle Domocol

APPROVED FOR THE DEPARTMENT OF ENVIRONMENTAL STUDIES

SAN JOSÉ STATE UNIVERSITY

December 2019

Lynne Trulio, Ph.D. Department of Environmental Studies

Kristin Byrd, Ph.D. United States Geological Survey

Kathryn Davis, Ph.D. Department of Environmental Studies 


\begin{abstract}
CLIMATE-DRIVEN INSECT HERBIVORY IN MIXED COAST LIVE OAK WOODLANDS WITHIN THE MT. HAMILTON RANGE, SANTA CLARA COUNTY

by Michelle Domocol
\end{abstract}

Climate change is expected to dramatically alter and destabilize critical functions of oak woodlands (Quercus spp.) in California. Oak woodlands support hundreds of vertebrate species and thousands of native insect species. Climate-driven changes in annual temperature, annual rainfall, and spatial climatic variability may increase insect herbivore pressures on mixed coast live oak (Quercus agrifolia) woodlands. The Mt. Hamilton Range of Santa Clara County, California offers a unique matrix to study oakinsect herbivore relationship using elevation as a proxy for climate change. This thesis research assessed the relationship between lepidopteran herbivory and coast live oak with insect surveys and the laboratory analysis of phenolic compound concentrations. Results were evaluated under two plant-herbivore theories, Resource Availability Hypothesis (RAH) and Plant-Size Apparency Hypothesis (PSAH). Results indicate elevation increased as mean annual temperature declined, confirming that elevation in this system is a suitable proxy for climate change. Relationships between herbivory, elevation and plant defense chemicals showed larger plant size correlated with higher herbivory.

Overall, the results did not support RAH and partially supported PSAH. Results suggest managers should use alternate hypotheses in combination with an elevational framework. As the climate changes, future elevational surveys may help managers understand how to best preserve Mt. Hamilton's oak woodlands. 


\section{ACKNOWLEDGEMENTS}

Thank you to my thesis committee members, Dr. Lynne Trulio, Dr. Kristin Byrd and Dr. Kathryn Davis. Their academic direction helped me formulate and execute my thesis. Thank you to Dr. Michael Loik, Dr. Brett Hall, Al Keuter and Dr. Rod Myatt for their expertise in climate change ecology and California oaks. Many thanks to the kind staff at my data collection sites. This includes Zac Harlow, Kostas Chloros, Karen Cotter, Will Bick, Henry Colletto and Bob Clement. Without their assistance, my elevational surveys would not be possible. I want to also acknowledge Teri Rogoway of the Santa Clara Valley Open Space Authority, Debbie Mytels of Acterra, Megan Fluke of Committee for Green Foothills, and Dr. Linda Anderson of University of California (Santa Cruz) for their environmental leadership and professional guidance. Thank you to California Native Plant Society (Santa Clara Valley) for their financial support.

I am indebted to my dear friend, David Chang, who introduced me to biodiversity hotspots and mountain ranges within this great California Floristic Province. His passion for Californian ecology and unwavering moral support bolstered my confidence at critical points in the master's program. Finally, I wish to thank my mother. She encouraged me to travel far and wide, through every winding road, to pursue my interests in environmental management. 


\section{TABLE OF CONTENTS}

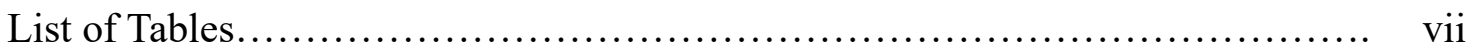

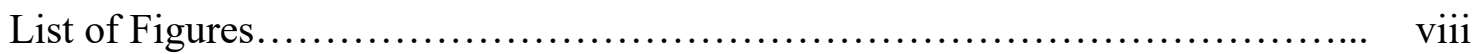

Introduction.............................................................. 9

Literature Review.................................................... 11

Climate Impacts and Plant-Insect Herbivore Relationships................. 11

Ecological Relationships in Californian Oak Woodlands.................... 15

Estimating the Impact of Climate in Oak-Insect Herbivore Relationships...... 16

Oak Herbivory Response to Temperature and Precipitation................. 22

Research Objectives................................................. 25

Research Questions.................................................... 28

Study Area....................................................... 29

Methods............................................................ 33

Data Analysis.................................................... 35

Results............................................................. 38

Discussion........................................................... 42

Recommendations................................................ 48

Future Research.................................................. 48

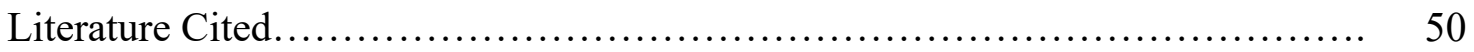




\section{LIST OF TABLES}

Table 1. Historic and Projected Annual Temperature Averages in Santa Clara

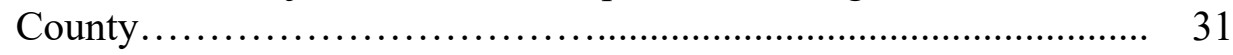

Table 2. Location of Oak Samples....................................... 33

Table 3. Oak Specimens and Temperature Per Elevation........................ 37

Table 4. No Relationships Between Oak Compounds and Elevation............... 40

Table 5. No Relationships Between Oak Compounds and Height................ 42 


\section{LIST OF FIGURES}

Figure 1. Expected multitrophic responses to climate change.............. 12

Figure 2. Coast live oak distribution in Santa Clara County................ 26

Figure 3. Oak sample sites and weather station locations................ 30

Figure 4. Target species and insect feeding pattern in herbivory surveys......... 34

Figure 5. Relationship between mean annual temperature and elevation

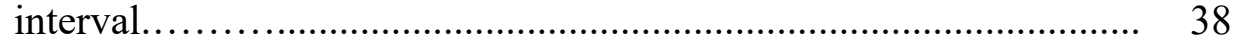

Figure 6. Leaf area loss per elevation and mean annual temperature................ 39

Figure 7. Mean quercetin levels per elevation ......................... 40

Figure 8. Individual oak diameter $(\mathrm{DBH})$ versus leaf area removed............... 41

Figure 9. Individual oak height versus leaf area removed................... 41 


\section{Introduction}

The ecological functioning of terrestrial ecosystems depends on a complex web of multiple trophic levels, biotic interactions (Anstett, Nunes, Baskett, \& Kotanen, 2016; González-Zurdo et al. 2016; Pellissier et al., 2012) and abiotic factors (Jamieson, Trowbridge, Raffa, \& Lindroth, 2012; Voelckel \& Jander, 2014). Vegetation and insect communities, the foundation of most terrestrial trophic complexes, (Abdala-Roberts et al., 2016; Buckley, Widmer, Mescher, \& De Moraes, 2019) are strongly influenced by regional climate, seasonal temperature and precipitation (Leckey, Smith, Nufio, \& Fornash, 2014; Rasmann et al., 2014; Voelckel \& Jander, 2014). Understanding multitrophic responses (i.e. diverse plant-insect interactions) to climate change will be essential to managing plant communities (Jamieson et al., 2012; Moreira, Petry, Mooney, Rasmann, \& Abdala-Roberts, 2017). Analyses that explain how herbivores mediate plants' response to climate change are necessary. Additionally, data from plant-insect surveys are needed to describe how plants mediate insect herbivores' response to climate change (Jamieson et al., 2012; Moreira et al., 2017). For example, researchers observe that, with climate warming, plants' phenological processes such as budbreak and leaf expansion can occur sooner than historic patterns (Jamieson et al., 2012).

Simultaneously, climate warming can cause higher rates of insects' larval development and overwinter survival (Jamieson et al., 2012; Haavik, Flint, Coleman, Venette, \& Seybold, 2019; Mclaughlin, Morozumi, MacKenzie, Cole, \& Gennet, 2014). Jamieson, Trowbridge, Raffa, and Lindroth (2012) observed that unseasonable warming during dry periods can result in heightened insect herbivory, vegetation mortalities, and impaired 
leaf development (Jamieson et al., 2012). However, these observed trends lack a complete analysis of mechanisms that mediate both plants' and insects' responses to climate change (Jamieson et al., 2012). With more plant-insect herbivore studies, researchers and managers can fully assess multitrophic responses associated with spatial climatic variability in local and regional areas (McLaughlin et al., 2014).

Despite increasing evidence that climate change is altering composition and multitrophic interactions, surveys on species' adaptations and responses remain limited (Buckley et al., 2019). The assessment of climate change consequences on insect herbivory and defense patterns in oak woodlands is increasingly imperative as oak habitat shrinks in biodiversity hotpots such as California (Brooks \& Merenlender, 2001). Mixed oak woodlands in Santa Clara County, California are particularly vulnerable to change as temperatures continue to rise over this century (Brown, 2018; Maizlish, English, Chan, Dervin, \& English, 2017). Climate-driven changes in annual temperature, rainfall, and spatial climatic variability are predicted to increase herbivore pressures on coast live oak woodlands in California (Hardy, Vreeland, \& Tietje, 2013).

To examine local and regional oak-herbivore relationships, researchers can employ elevational surveys as a proxy for climate change (Körner, 2000). Santa Clara County provides an excellent location to study elevational insect herbivory and plant defense concentrations. Resident oaks are distributed over elevations from sea level to $1050 \mathrm{~m}$ (Calflora, 2019). Lepidoptera larvae are primary foliar feeders of Santa Clara County oaks. Further, Lepidoptera such as Adelpha californica, Erynnis propertius, and Erynnis tritius, support higher trophic levels in Santa Clara County's oak woodlands (Shapiro, 
2007). As pollinators and prey for birds, bats and other insectivores in the county's oak woodlands, Lepidoptera significant ecological roles (Shapiro, 2007). Oak woodlands in Santa Clara County clearly offer suitable elevational characteristics and multitrophic relationships for elevational oak herbivory studies.

Several hypotheses predict how climate-driven herbivory impacts on plants, including the Resource Availability Hypothesis. However, current elevational surveys on oak defenses, insect herbivory rates and herbivore pressure are inconclusive, driving the need for additional studies (McClaughlin et al., 2014; Peters, Schwartz, \& Lubell, 2018; Rasmann et al., 2014; Voelckel \& Jander, 2014). California is a biodiversity hotspot at risk of significant species loss due to climate change. The results from this thesis research on elevational oak-lepidopteran interactions can inform local and regional climate adaptation as well as biodiversity conservation in Santa Clara County (AbdalaRoberts et al., 2016; González-Zurdo, Escudero, Nuñez, \& Mediavilla, 2016; Pearse, 2011).

\section{Literature Review}

\section{Climate Impacts and Plant-Insect Herbivore Relationships}

Climate change is predicted to impact ecosystems at the organism, population and community level (González-Zurdo et al., 2016; Pardikes, Shapiro, Lee, \& Forister, 2015; Rasmann et al., 2014). At the organismal level, climate change may alter individual physiological processes such as growth, phenology and mortality rates of host vegetation and insect herbivores (Bale et al., 2002; Kingsolver \& Buckley, 2018) (Figure 1). These interacting ecological processes are known as multitrophic responses. 


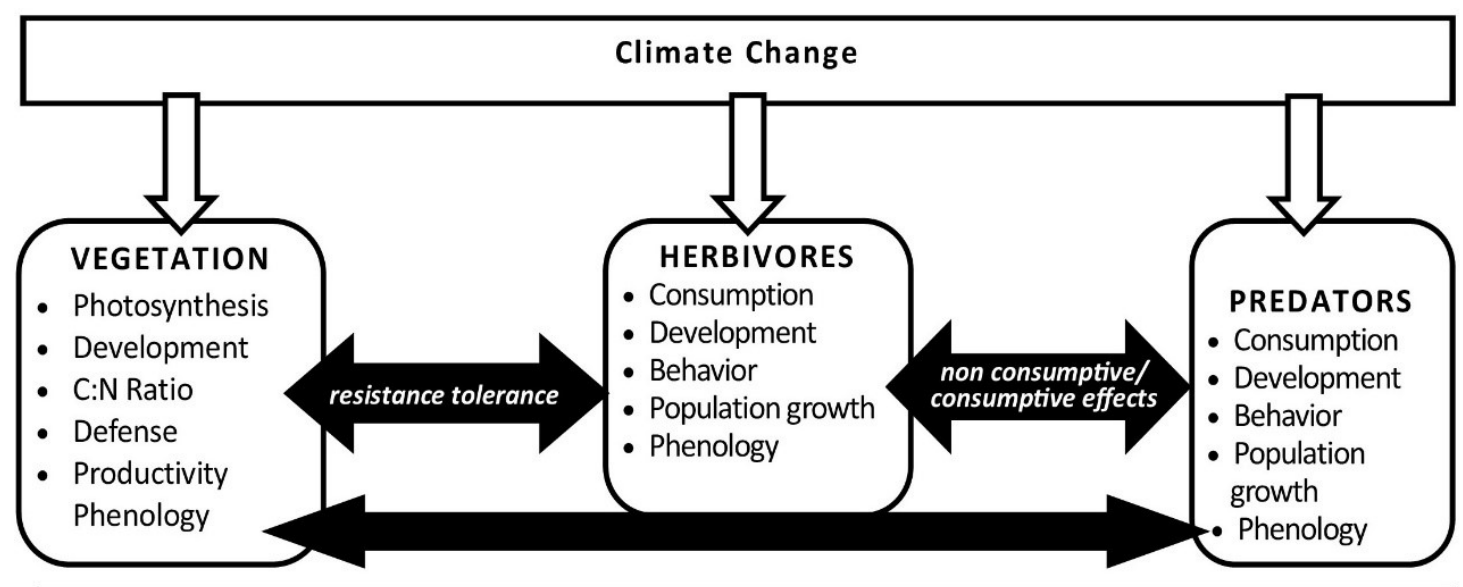

Trophic Cascades | Altered Phenology \& Chemical Signaling | Resource Quality

Figure 1. Expected multitrophic responses to climate change. Hollow arrows within the figure point to direct effects of climate change on species traits. Black arrows indicate direct effects resulting from altered trophic interactions. Traits are identified inside the black arrows. The bottom box highlights indirect effects that can influence species interactions between and across trophic levels. Adapted from Jamieson et al., 2012.

Host-plants and insect herbivores are the foundation of higher trophic levels and their interactions drive community-level dynamics. (Voelckel \& Jander, 2014; Zehnder \& Hunter, 2008). Insect herbivory plays a major role in shaping plant community diversity and composition (Gallou, Baillet, Ficetola, \& Després, 2017; Kergunteuil, Descombes, Glauser, Pellissier, \& Rasmann, 2018; Pardikes et al., 2015). As climate becomes less favorable for insect development, these herbivores may become progressively less successful at completing their life cycle on specific host-plants (Bale et al., 2002; Leingärtner, Hoiss, Krauss, \& Steffan-Dewenter, 2014).

In addition, climatic events such as advanced or delayed snowmelt can lead to phenological desynchronization. Phenological desynchronization occurs when plant or insect growth becomes out-of-phase with other aspects of the ecological environment (Kessler, Poveda, \& Poelman, 2012; Kergunteuil et al., 2018; Leingärtner et al., 2014). 
Plant and insect phenology are cued by temperature, climate and photoperiods, all of which can be disrupted by climate change. Studies show insect herbivores and their associated host-plants respond to unseasonable warming with phenological desynchronization. Moreover, Bale et al. (2002) reported insects can produce unexpected colonies when cued by recent unstable climate and unseasonable temperature increases. As a result, host-plants may not develop the defenses to counter early upsurges in herbivore colonies (Bale et al., 2002).

Studies of European and southern California oak woodlands indicate that extreme thermal changes can directly influence insect herbivore development, reproduction, and survival (Voelckel \& Jander, 2014). Several cases that highlight Lepidoptera with limited distributions indicate their host-plants were vulnerable to climate impacts (Gallou et al., 2017; Kerguntil et al., 2018; Kingsolver \& Buckley, 2018; Pardikes et al., 2015). Gallou, Baillet, Ficetola, and Després (2017) suggest the decrease in plant diversity was associated with lowered butterfly species richness. This decline in plant diversity was specifically due to stressful climatic conditions such as novel low temperatures. As a result, specialist butterfly larvae were unable to find their preferred host-plants. In addition, Gallou et al. (2017) found abnormally low temperatures inhibited complete larval life cycles.

Other investigations emphasize that, unlike their sessile host-plants, some insect populations can respond to climatic variability with new migratory patterns and quick range shifts (Abdala-Roberts et al., 2016; de Sassi, Lewis, \& Tylianaki, 2012; Moreira et al., 2017). Novel migrations and immediate range shifts produced rapid trophic 
mismatches between insect herbivores and host-plants (Abdala-Roberts et al., 2016; de Sassi et al., 2012). Trophic mismatches are closely tied with phenological desynchronization. Since insect herbivores are more sensitive to thermal changes, their development, reproduction and population dynamics are directly influenced by climate change. Bale et al. (2002) found certain Lepidoptera such as Pieris brassicae will disperse to new habitats and shift their demographic range. In turn, insect herbivores might defoliate different host-plants unable to resist new colonies of herbivores (Bale et al., 2002). In northern California, oak woodlands with increased climate-related herbivore pressure exhibited lower host-plant productivity, higher mortality rates, and severe leaf damage rates (Leckey et al., 2014; Pearse, 2011).

Moreover, related research predicts unseasonable oscillations in herbivore population density may lead to herbivore population increases and rapid host-plant declines (Pellissier, Aurélien, Bilat, \& Rasmann, 2014). These predictions suggest climateinduced insect defoliations may lead to modified oak canopy development, and higher mortalities in oak overstory and associated understory host-plants (Kessler et al., 2012). Compared to insects, vulnerable, sessile host-plants may slowly adapt their geographic range to the new climate stressors (Forister et al., 2010). These novel migration rates will result in trophic mismatches or reshuffled plant and insect communities (Casner, et al., 2018). Changes in herbivore populations can negatively affect plant community composition and community-level functional traits (de-Dios-García, Manso, Calama, Mathieu, \& Pardos, 2018; de Sassi et al., 2012; Mclaughlin et al., 2014). 


\section{Ecological Relationships in Californian Oak Woodlands}

Regional and local taxa-specific analyses are necessary to understand and manage climate impacts on oak woodland ecosystems in central California (Machuca, Ferreira, Martinez, \& Santos, 2011; Voelckel \& Jander, 2014). Elevational surveys investigate how abiotic conditions and climate change may degrade or disrupt vital multitrophic relationships (Rasmann et al., 2014) in Californian oak woodlands. In California, oak woodlands are widespread and support approximately 300 species of terrestrial vertebrate wildlife, 370 fungi, and approximately 5,000 insect species (Barry et al., 2005; SFEI, 2017; Zack, Chase, Geupel \& Stralberg, 2005). At least 169 terrestrial mammal species depend on oak woodlands for food, shelter, or cover (Barry et al., 2005).

Coast live oak woodlands (Quercus agrifolia) provide significant host-plants, food sources, protective cover, nesting sites, and corridors for a diversity of native invertebrates, avian species, reptiles and amphibians, and mammals (Barry et al., 2005; SFEI, 2017). The oak woodland understory assemblage includes endemic shrubs, such as manzanita species (Arctostaphylos spp.), and trees like buckeye (Aesculus californica), madrone (Arbutus menziesii), wild cherry (Prunus ilicifolia), and California bay laurel (Umbellularia californica) (SFEI, 2017). Oak communities also include several keystone terrestrial species like mountain lions (Puma concor) and predators such as coyotes (Canis latrans) and bobcats (Lynx rufus) (Costello, Hagen, \& Jones, 2012).

Wildlife and floristic communities rely on stable ecological functions of oak woodlands (Costello et al., 2012). For instance, Californian oak woodlands provide the production high volumes of biomass and uptake significant amounts of nitrogen and 
carbon to resident flora and fauna (Coleman et al., 2011; Scott, Turner, Washington, \& Corella, 2015). Resident predators, herbivores, understory vegetation and decomposers depend on oak woodland litter decomposition, soil stabilization, and water quality regulation (Rasmann et al., 2014; SFEI, 2017). Biodiverse coast live oak woodlands support productive soil and protect the integrity of regional watersheds (Tietje, Purcell, \& Drill, 2005). Oak canopy layers produce high volumes of biomass, take up nitrogen and carbon, and decompose litter (Hardy et al., 2013). Biomass production and leaf litter decomposition increase soil organic matter and fertility of woodland soils (Costello et al., 2012; Tietje et al., 2005).

Unstable temperature and climate are forecasted to threaten the stability of oak woodland vegetation. Average maximum and minimum temperatures in regions of central California are projected to be higher than historic average maximum temperatures (Cal-Adapt, 2019; Langridge, 2018). With average temperature increases, principal multitrophic interactions and ecological functions of oak woodlands may deteriorate (Coleman et al., 2011; Kingsolver \& Buckley, 2018; SFEI, 2017).

\section{Estimating the Impact of Climate in Oak-Insect Herbivore Relationships}

Multitrophic plant-insect herbivore responses to climate factors still require thorough, systematic analysis of oak-insect relationships (Pardikes et al., 2017). Elevation gradients can be optimal tools to infer climate change dynamics (Boscutti et al., 2018). Since air temperature can decrease by $5.5 \mathrm{C}^{\circ}$ per vertical kilometer, many studies use elevation as a proxy for temperature and climate change conditions (Körner, 2007). The spatial variation in climatic factors such as temperature represent strong environmental 
pressures on ecosystems that mirror climate change conditions (Dunne, Saleska, Fischer, \& Harte, 2004; Pfennigwerth, Bailey, \& Schweitzer, 2017). The use of elevation gradients to infer climate change responses can minimize the confounding effects of historical and biogeographical differences in plant responses (Andrew, Roberts, \& Hill, 2012; Kershaw, Ducey, Beers, \& Husch, 2016; Pellissier et al., 2014; Rasmann et al., 2014).

Numerous hypotheses predict specific plant defense trends and multitrophic responses to abiotic factors, such as climate change. The Resource Availability Hypothesis (RAH) is one such well-known theoretical approach (Körner, 2007; McLaughlin et al., 2014; Pellissier et al., 2012). RAH suggests that multitrophic trends are driven by ecological gradients such as elevation, temperature, and precipitation (Rasmann et al., 2014; Voelckel \& Jander, 2014). Using elevation as a proxy for temperature, researchers have employed the RAH framework to investigate climate change responses of plant-insect population dynamics (de Sassi et al., 2012), herbivore pressure, herbivore assembly, and host-plants' defensive trait expression (de-Dios-García et al., 2018; Hahn \& Maron, 2016). Essentially, the RAH framework can be used to assess the degree of influence climate may have over plant-insect herbivore relationships (Kessler et al., 2012; Galmán et al., 2018; Moreira et al., 2017). RAH posits that plant defense traits, such as foliar nitrogen, defensive chemistry, structural compounds, and leaf morphology traits, will change with climate stress and with other varying elevational conditions (Galmán et al., 2018; Rasmann et al., 2014). Plant defenses are anticipated to 
change according temperature stressors, biotic impacts, and degrees of herbivore pressure (Descombes et al., 2017; Kergunteuil et al., 2018).

At lower elevations, RAH predicts that limiting abiotic conditions are reduced. Lower elevations are characterized with less resource stress, warmer conditions, and less wind (Buckley et al., 2019; Moreira et al., 2017). As a response to favorable conditions, lower elevation habitats should exhibit higher levels of growth, abundance and diversity than higher elevations (Moreira et al., 2017). At lower elevations, tree species more successfully counter insect herbivory with potent foliar defensive compounds (Anstett et al., 2016; Hahn \& Maron, 2016). In response, to the higher herbivory, increased leaf area loss and frequent insect outbreaks, lower elevation plants use chemical defense to maintain abundance and fitness (Abdala-Roberts et al., 2016; Pearse, 2011). At lower elevations, plant chemical defenses include secondary metabolites, induced defenses, direct and indirect defenses (e.g. volatile organic compounds and glucosinolates) (Defosezz, Pellissier, \& Rasmann, 2018; Tietje et al., 2005; Rasmann et al., 2014; Voelckel \& Jander, 2014). Foliar defensive compounds also include tannins, phenolics, and terpenoids (Anstett et al., 2016; Kessler et al., 2012; Mizumachi, Mori, Akiyama, Tokuchi, \& Osawa, 2012). Since they depend more on defensive compounds, lower elevation vegetation is expected to express fewer physical resistance traits and resource allocation strategies (Abdala-Roberts et al., 2016; Defosezz et al., 2018; Rasmann et al., 2014; Tscharntke \& Hawkins, 2002; Voelckel \& Jander, 2014).

At higher elevations, plants are predicted to adapt to resource stress and harsh conditions with slow growth (Kessler et al., 2012). Slow-growing vegetation is expected 
to defend against lower insect diversity and decreased herbivory (Anstett et al., 2016; Defosezz et al., 2018; Hahn \& Maron, 2016). High elevation plants can also resist defoliation with enhanced physical defense traits and morphological resource allocation strategies (Copolovici et al., 2017; Leckey et al., 2014; Rasmann et al., 2014). Morphological defenses include the development of protective leaf shapes, increased leaf thickness, protective epicuticular wax layer or increased plant size (Hahn \& Maron, 2016; Jamieson et al., 2012; Kergunteuil et al., 2018; Pellissier, et al., 2014). These physical strategies protect and regulate leaf development, leaf's photosynthetic potential, and leaf permanence (Descombes et al., 2017). High elevation vegetation also expresses resource allocation strategies that redirect resources away from herbivore-damaged sites, decrease leaves' palatability and lower leaves' nutritive value (Defosezz et al., 2018).

A survey of elevational RAH studies indicated that over $60 \%$ provided evidence supporting the predictive trends of RAH (Moreira et al., 2017). These studies' findings supported elevational changes in herbivory plant defense investment (Pellissier, et al., 2014; Mclaughlin et al., 2014; Voelckel \& Jander, 2014). However, many other studies have not confirmed the expected relationships (Casner et al., 2014; Espeset et al., 2016). For example, two community-level examinations of plot surveys and meta-analyses reported elevation lacked any influence over woodland plant-herbivore relationships (Pellissier et al., 2012; Rasmann et al., 2014). In addition, recent analyses report high herbivory levels in upper elevations, rather than lower levels as predicted by RAH (McClaughlin et al., 2014; Peters et al., 2018; Rasmann et al., 2014; Voelckel \& Jander, 2014). A recent review by Moreira et al. (2017) refuted the expected elevational trends in 
chemical defense investment (Abdala-Roberts et al., 2016; Buckley, Pashalidou, et al., 2019; De Long et al., 2015; Koptur, 1985; Pellissier et al., 2014; Rasmann et al., 2014;). Other inquiries report non-linear or the absence of associations with elevation (Dostálek, Rokaya, \& Münzbergová, 2018; Louda \& Rodman, 1983; Pellissier et al., 2014). Since plant defense mechanisms may have drivers other than, or in addition to, elevation, researchers suggest it is important to consider selective biotic and abiotic forces that can shape the patterns of defense investment along elevation gradients (Buckley et al., 2019). RAH predictions related to the influence and mediation of population size, predator to herbivore ratios, chemical defense diversity is largely untested in various montane, woodland ecosystems (Leingärtner et al., 2014). Consequently, the influence of elevation on herbivore pressure and other biotic interactions is highly debated (Agne et al., 2018; Leingärtner et al., 2014; Moreira et al., 2017).

Beyond the Resource Availability Hypothesis, there are additional theories and explanatory models for plant-insect herbivore relationships and plant defense mechanisms. One popular and well-tested hypothesis focuses on morphological plant defense strategy of increased plant size (Pellissier, et al., 2014). This framework is called the Plant-Size Apparency Hypothesis (PSAH). Other plant defense explanatory models include the Optimal Defense Theory and the Feeding Specialization Hypothesis. The Plant-Size Apparency Hypothesis (PSAH) predicts larger plants are apparent or easily found by herbivores and other associated organisms (Blanckenhorn, 2000; Hemptinne, Magro, Evans, \& Dixon, 2012). This morphological trait to higher plant palatability, higher vigor and lower chemical resistance than smaller, less visible plants (Feeny, 
1976). PSAH posits chemical defenses from apparent and unapparent plants differ (Schlinkert et al., 2012). Moreover, the hypothesis emphasizes a plant's morphological investment in larger size often relates to greater dispersal ability, enhanced competitiveness for resources, and higher attractiveness to both beneficial organisms and insect defoliators (Remmel \& Tammaru, 2009; Schlinkert et al., 2012). The attractiveness of larger plants may also be higher as they can offer large microhabitat for insects (Schlinkert et al., 2012). Several case studies support the PSAH. One study showed the large host-plants increased their leaf digestibility to larvae when signaled by the oviposition by female winter moths (Schlinkert et al., 2012). The plants' digestibility increased with heightened leaf tannins and lowered proteins (Remmel \& Tammaru, 2009). Other cases report the effects of unapparent plants displayed a different multitrophic and phenological relationship to herbivores. For instance, cruciferous plants such as Pieris rapae avoid specialist insect herbivores with decrease plant size (Schlinkert et al., 2012). Additionally, generalist insect herbivores are deterred by the cruciferous plant's emission of volatile foliar chemical defenses.

The Feeding Specialization Hypothesis presents an alternative, nuanced perspective to PSAH (Termonia, Hsiao, Pasteels, \& Milinkovitch, 2001). This hypothesis asserts specialist herbivore species prefer unapparent plants rather than apparent plants (Termonia et al., 2001). Studies that support this theory indicate specialist butterfly species prefer unapparent herb hosts, while moth species feed on apparent tree and larger understory species (Gómez-Zurita, Juan, \& Petitpierre, 2000). 
An alternate plant defense explanatory model is the Optimal Defense theory (ODT) (Alba, Bowers, \& Hufbauer, 2012). ODT posits that vegetation with limited resources use chemical defenses to increase the fitness of their plant tissues and prevent attacks from insect defoliators, pathogens, and other types of herbivores (Cates, 1980). ODT asserts that herbivores are the main mediators of plants' evolutionary selection of toxic or deterrent chemical defenses (Buschmann, Edwards, \& Dietz, 2005). As a result, insect herbivores contribute to the host-plant's fitness and population dynamics (Buschmann, et al., 2005).

\section{Oak Herbivory Response to Temperature and Precipitation}

Researchers emphasize the importance of monitoring elevational temperatures and the effects on host oak defenses, insect herbivore interaction, oak life-history characteristics and distributions. The direct effects of temperature and precipitation on insects are likely to differ among oak and associated host species (Casner et al., 2014; Gallou et al., 2017; Kerguntil et al., 2018). Woodland management and oak's potential adaptive capacities may help oaks resist deleterious effects of changing temperature conditions (Tscharntke \& Hawkins, 2002; Voelckel \& Jander, 2014).

Changes in annual temperature and precipitation may drive the altered migratory patterns and range distribution of oak herbivores (Moreira et al., 2017; Rasmann et al., 2014). Findings already suggest regional temperature rise is likely to affect insect morphology and demographic patterns (Bale et al., 2002; Speed, Austrheim, Hester \& Mysterud, 2012). Altered insect colonization, increased herbivore attacks and decreased host-plant fitness are direct multitrophic responses (Tscharntke \& Hawkins, 2002; 
Voelckel \& Jander, 2014). A study by Leckey, Smith, Nufio, \& Fornash (2014) indicated that climate change impacts on annual temperature in California may destabilize populations of specialists and generalist feeding insects, such as Lepidoptera. In contrast, Galmán et al. (2018) found, with four European oak species, temperature was not correlated with most measures of herbivory. The contrast in findings may indicate the effects of herbivory may vary with location and specific regional abiotic conditions (Leckey et al., 2014). Many case studies have demonstrated that drought stress and precipitation regimes can affect the abundance, development, and distribution of plants and insects, while also affecting the nutritional quality and defenses of plants (de Sassi et al., 2012; Jamieson et al., 2012; Körner, 2007). Foliar feeders such as gall formers or leaf miners are increase their feeding rates and actual leaf area loss during high precipitation (Galmán et al., 2018). Precipitation-associated changes in plants and insects may influence the type and strength of interactions that occur between these two groups (Coleman et al., 2011; Galmán et al., 2018).

Elevational insect herbivory research shows that shifts in precipitation, temperature, climate, and biotic conditions impact to oak woodland defensive chemistry (Haavik et al., 2015; Jamieson et al., 2012; McLaughlin et al., 2014). Researchers suggest some hostplant species that historically relied on physical defenses will produce novel defensive chemistry (Rasmann et al., 2014; Voelckel \& Jander, 2014). Vegetation is expected to respond to climate stress with higher levels of constitutive direct defenses such as glucosinolates (de-Dios-García et al., 2018; de Sassi et al., 2012; Descombes et al., 
2017). Glucosinolates are secondary metabolites synthesized in plant tissue (Barba et al., 2016) that deter insect defoliators (Barba et al., 2016).

An elevational study found European mediterranean oak species in lower elevations exhibited a novel increase of herbivore-induced phenolic compound concentrations to resist novel lepidopteran attacks (Rasmann et al., 2012). Similarly, Leckey et al., (2014) observed that northern California oaks, at lower elevations, produced increased concentrations of total phenolics and proanthocyanins (condensed tannins) to resist an unseasonable upsurge in lepidopteran herbivory. Similarly, Mizumachi, Mori, Akiyama, Tokuchi, \& Osawa (2012) found that at upper elevations in Japan, oaks (Quercus serrata) adjusted their physiological and morphological properties as a response to novel herbivore attacks. These studies reveal oaks can respond with phenotypic plasticity and induce stronger foliar defensive compounds to adapt to new herbivory patterns (Leckey et al., 2014; Mizumachi et al., 2012). The development of stronger herbivore resistance may show how plants can mitigate novel herbivore outbreaks and increased defoliation in future periods of unseasonable climate warming (Tscharntke \& Hawkins, 2002; Voelckel \& Jander, 2014). Locally focused studies of oak responses to climate change using elevational studies can be used to assess whether hosts can effectively defend against novel herbivore pressures (Descombes et al., 2017; Mizumachi et al., 2012). Given the variability in oak community responses, managers need local studies that assess oakherbivory interactions under different climate, temperature and precipitation regimes (Descombes et al., 2017). 


\section{Research Objectives}

Santa Clara County oak woodlands provide an opportunity to study oaks and their lepidopteran herbivores under a range of elevational conditions. Santa Clara County is located at the southern end of the San Francisco Bay in California (SFEI, 2017). The county encompasses 1,312 square miles which includes Santa Clara Valley (SFEI, 2017). The Mt. Hamilton Range is a belt of mountains that lie east of the Santa Clara Valley. Mixed coast live oak woodlands cover approximately 11,696 hectares of the Mt. Hamilton Range (Figure 2). The range's elevation extends from sea level to 1,399 m (Barry et al., 2005; Grossinger, Striplen, Askvold, Brewster, \& Beller, 2007; SFEI, 2017).

Oak communities within the Mt. Hamilton Range include coast live oaks, oak hybrids, blue oak (Quercus douglasii) woodlands, valley oak (Quercus lobata) woodlands, foothill pine-oak woodlands (Pinus sabiniana), interior oak (Quercus wislizeni) chaparral, leather oak (Quercus durata) chaparral and black oak (Quercus kelloggii) woodlands. Many of the communities overlap and lack sharp boundaries. 


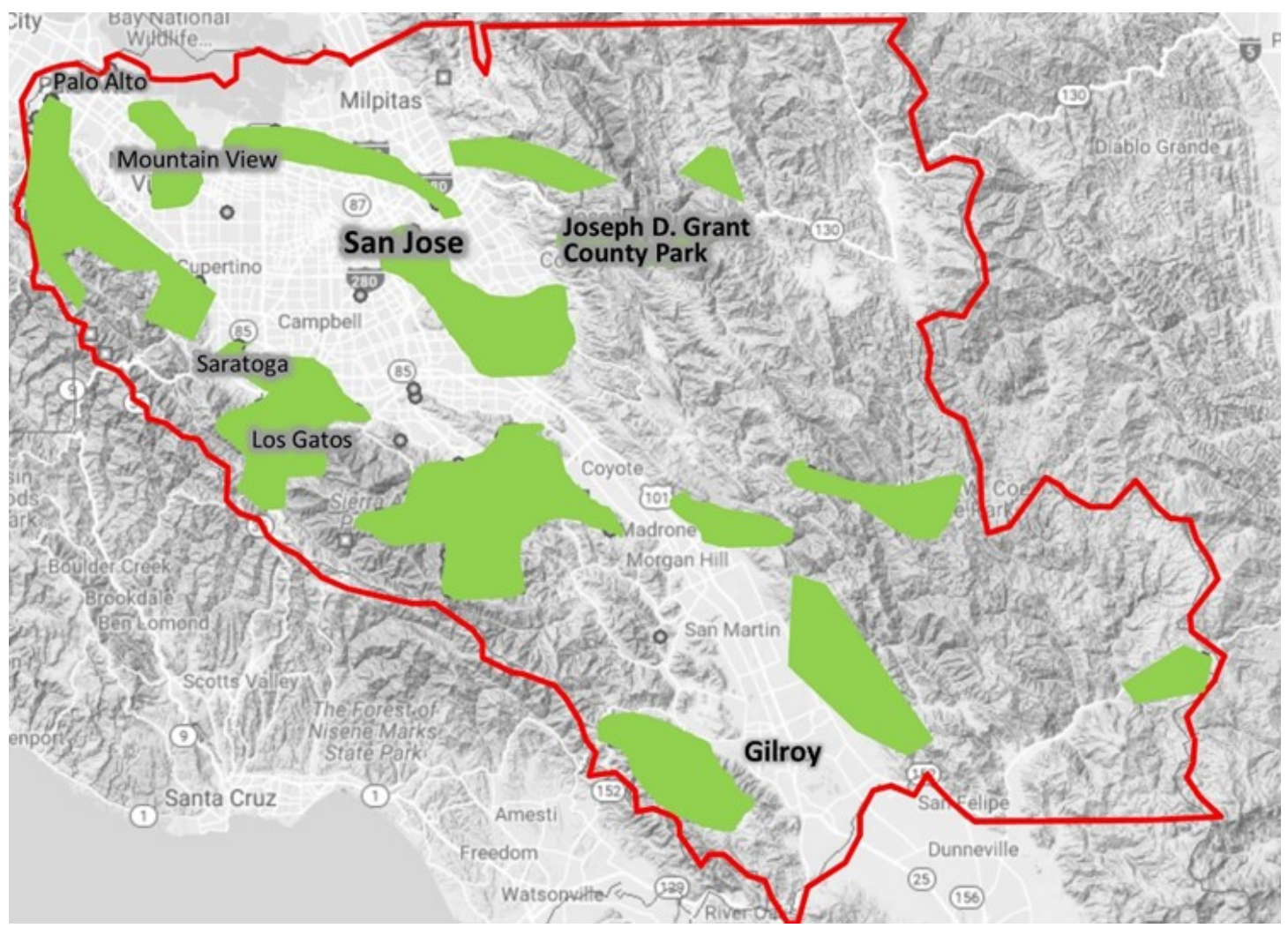

Figure 2. Coast live oak distribution in Santa Clara County. Solid, green patches indicate areas with coast live oaks. Adapted from "Observation Hotline: Quercus agrifolia," by Calflora, 2019.

Understanding the oak-lepidopteran responses to changing temperature and precipitation patterns can provide guidance for managing oak woodlands in Santa Clara County as the climate changes (Brooks \& Merenlender, 2001; Grossinger, et al., 2007). Researchers and oak woodland managers in Santa Clara County should monitor patterns of phenological disruption, trophic mismatches and biogeographical shifts in oak defoliators such as Lepidoptera (Brooks \& Merenlender, 2001; Grossinger, et al., 2007). Studies on lepidopteran responses to climate change will help managers predict and possibly mitigate the occurrence of outbreaks. These plant-herbivore studies may also reveal oaks' defense and response to unseasonable lepidopteran upsurges. California 
coast live oaks in Santa Clara County are projected to experience rising temperatures by the end of this century (Maizlish et al., 2017). Average maximum temperatures in Santa Clara County are projected to be $3.8^{\circ} \mathrm{C}$ higher than historic maximum temperatures (CalAdapt, 2019; Langridge, 2018). High carbon emissions models foresee increased average temperatures, more frequent extreme heat events, flooding and extreme storms in Santa Clara County (Langridge, 2018). Thirty-year averages of annual rainfall in Santa Clara County are projected to increase from 38.6 centimeters to 45.2 centimeters by the end of the century (Cal-Adapt, 2019; Langridge, 2018).

Elevational plant-herbivore and plant defense studies can assess how herbivore pressures on coast live oak woodlands may change with increasing temperature and precipitation (Rasmann et al., 2014; Voelckel \& Jander). The Resource Availability Hypothesis and Plant-Size Apparency Hypothesis are possible theoretical frameworks to evaluate herbivory rates, defense patterns and abiotic influences (McClaughlin et al., 2014; Peters et al., 2018). Studies have found variability in the temperature-mediated responses to herbivores highlight the need for local, climate-driven elevational herbivory studies (Casner et al., 2014; Leckey et al., 2014). Local studies will ensure effective conservation and management of local ecosystems (McClaughlin et al., 2014; Peters et al., 2018; Rasmann et al., 2014; Voelckel \& Jander, 2014).

This case study addresses the following research questions and hypotheses to assess climatic variability, using elevational change, on oak-lepidopteran interactions in the Mt. Hamilton Range of Santa Clara County oak woodlands. 


\section{Research Questions}

1. Do rates of observed native lepidopteran larvae herbivory support the expected patterns of elevational herbivory and plant chemical defense concentrations as predicted by the Resource Availability Hypothesis or the Plant-Size Apparency Hypothesis?

2. To what extent are abiotic factors such as mean annual temperature associated with elevational insect herbivory? Given the results, what are the implications for oak woodland management practices?

Null Hypotheses:

1. In the Mt. Hamilton range, mean annual temperature and elevation are not significantly related.

2. Native lepidopteran (Nymphalidae) larvae herbivory rates, as measured in percentages of leaf area removed, in coast live oak clusters do not differ along elevations from $350 \mathrm{~m}$ to $1050 \mathrm{~m}$.

3. Concentrations of these phenolic compounds, kaemphferol, quercetin, gallic acid, ellagic acid, do not differ by elevation from 350 - $1050 \mathrm{~m}$ in coast live oak leaves.

4. Lepidopteran herbivory rates are not related to coast live oak diameter at breast height $(\mathrm{DBH})$ or height.

5. Concentrations of these phenolic compounds, kaemphferol, quercetin, gallic acid, ellagic acid, are not related to coast live oak diameter at breast height $(\mathrm{DBH})$ or height. 


\section{Study Area}

Data were collected from September to December 2018 and March to May 2019 in the Mt. Hamilton Range, Santa Clara County, California. The data collection sites of this study are Lick Observatory, Grant Ranch County Park, Blue Oak Ranch Reserve, and Cañada de los Osos Ecological Reserve (Figure 3). 


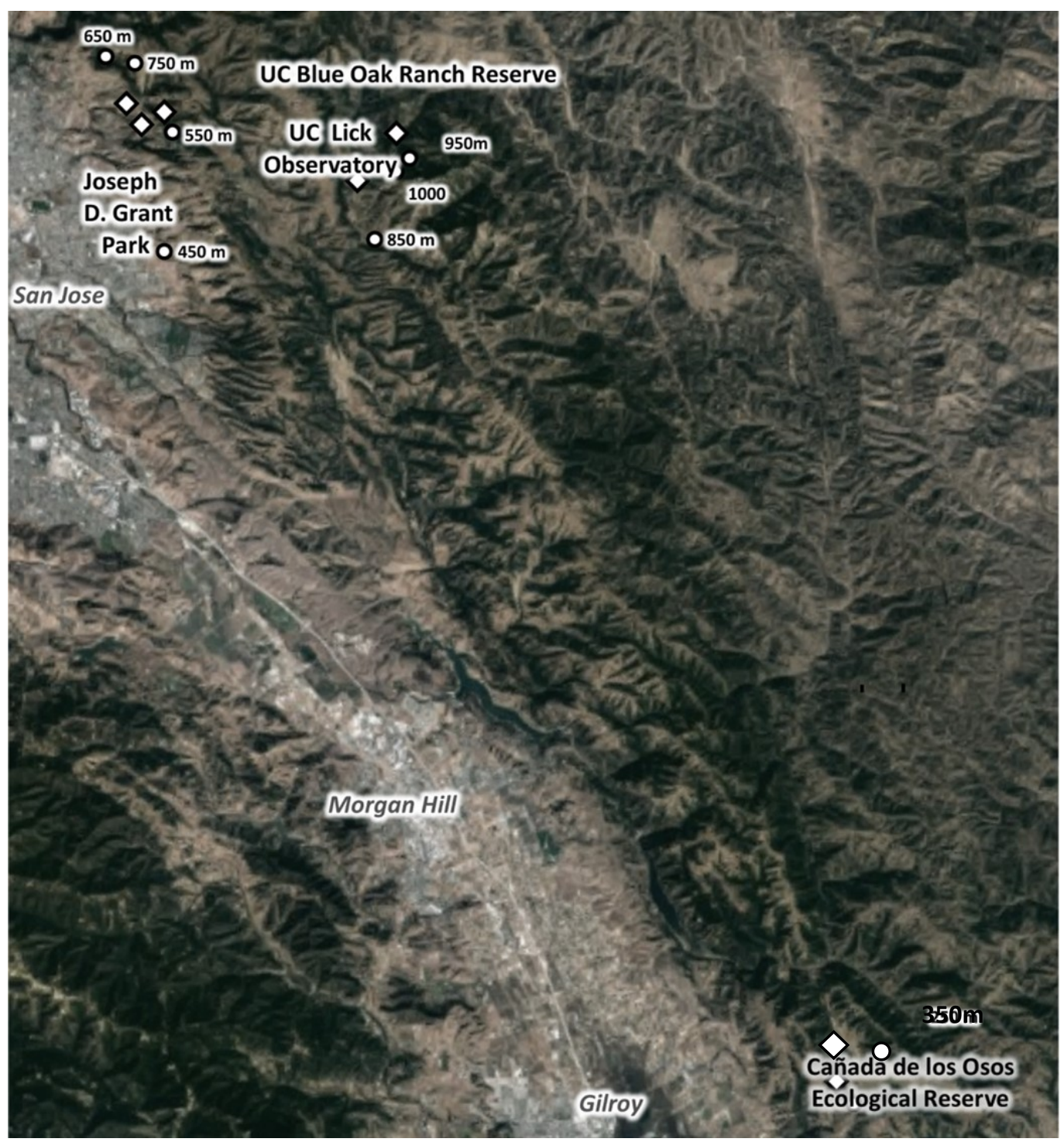

Figure 3. Oak sample sites and weather station locations. Hollow circles indicate sampling areas and diamond symbols represent weather station sites. Elevation is indicated next to sample site. Adapted from "Mt. Hamilton, San Jose, CA" by Google, 2019.

The Mt. Hamilton Range, with its summit at 1,399 m, is part of the Diablo Range and lies on the east side of Santa Clara County. Within each sampling site is a variety of grasslands, mixed oak woodlands, chamise chaparral, riparian vegetation and abundant faunal diversity. 
The elevation and temperature gradient at Mt. Hamilton Range was expected to act as a proxy for climate variation and the region's predicted climate increase. Average annual temperatures in lower elevations of the Mt Hamilton are $33^{\circ} \mathrm{C}$, while high elevations average $25^{\circ} \mathrm{C}$ (Langridge, 2018). Average maximum and minimum temperatures in Santa Clara County are projected to be $3.8^{\circ} \mathrm{C}$ and $3.9^{\circ} \mathrm{C}$ higher, respectively, than historic temperatures (Cal-Adapt, 2019; Langridge, 2018). These projections are according to two climate model climate model simulations called HadGEM2-ES and MIROC5 (CalAdapt, 2019). The HadGEM2-ES is simulation model that forecasts warmer and drier years in the Mt. Hamilton area. The MIROC5 model provides alternate climate scenarios beyond warm/dry, cool/wetter and average simulation models (Cal-Adapt, 2019). Table 1 lists the 30-year annual average maximum and minimum temperatures in an 8.5 Representative Concentration Pathway (RCP) scenario (Cal-Adapt, 2019; Langridge, 2018). RCPs describe alternative trajectories for carbon dioxide emissions and the resulting atmospheric concentration from 2000 to 2100 (Cal-Adapt, 2019).

Table 1

Historic and Projected Annual Temperature Averages in Santa Clara County

\begin{tabular}{lcc}
\hline & $\begin{array}{c}\text { Historic 30-year } \\
\text { Annual Average }\end{array}$ & $\begin{array}{c}\text { Projected 30-year average } \\
\text { the end of century }\end{array}$ \\
\hline Maximum Temperature $\left({ }^{\circ} \mathrm{C}\right)$ & 21.9 & 25.8 \\
\hline Minimum Temperature $\left({ }^{\circ} \mathrm{C}\right)$ & 10.2 & 14.1 \\
\hline
\end{tabular}

Note. Temperatures represent historic and project annual temperatures averages in Santa Clara County under an 8.5 RCP Scenario. This Representative Concentration Pathway (RCP) scenario assumes greenhouse gas emissions will rise through 2015 and plateau around 2100. Adapted from "Annual Averages" by Cal-Adapt, 2019. 


\section{Methods}

Data were collected from September to December 2018 and March to May 2019 in the Mt. Hamilton Range of Santa Clara County, CA (Figure 3). Data collection methods included three components: 1) standing herbivory surveys; 2) plant defense chemical laboratory analysis; and 3) vegetation community surveys. The data collection sites of this study are Lick Observatory, Grant County Park, Blue Oak Ranch Reserve and Cañada de los Osos Ecological Reserve. Lick Observatory sits atop Mt. Hamilton while mid to lower elevation sites such as Blue Oak Ranch Reserve and Joseph Grant County Park sit on the slopes of the Mt. Hamilton Range. All sampling sites had northerly aspects. Blue Oak Ranch Reserve's elevation range is $454 \mathrm{~m}$ to $870 \mathrm{~m}$ above sea level adjacent to Grant County park. Grant County park's elevation ranges from $427 \mathrm{~m}$ to 853 $\mathrm{m}$ above sea level. The lowest elevation sites are in Cañada de los Osos Ecological Reserve. This site sits east of Gilroy in the southern portion Santa Clara County. The Mt Hamilton Range was also selected for its vulnerable habitats, protected wildlife corridors, resident live oak community composition, structure, and habitat value (SFEI, 2017; Tietje et al., 2005).

Site selection was modeled after the experimental design of Leckey et al. (2014). Individual oaks were sampled at 100-meter intervals between elevations of $350 \mathrm{~m}$ to $1050 \mathrm{~m}$ in order to provide a gradient in temperature conditions. Herbivory rates of native lepidopteran larvae were collected from March to May 2019. The target individuals were mature coast live oaks and saplings of at least $1.2 \mathrm{~m}$ in height and a total 
of 502 individual specimens were sampled over the different elevations at the four sites (Table 2).

Table 2

Location of Oak Samples

\begin{tabular}{lcc}
\hline \multicolumn{1}{c}{ Data Collection Site } & $\begin{array}{c}\text { Total Number of } \\
\text { Individual Specimens } \\
\text { Sampled (n) }\end{array}$ & Elevation (m) \\
\hline Cañada de los Osos & 65 & 350 \\
Ecological Reserve & 76 & 450 \\
Cañada de los Osos & & \\
$\quad$ Ecological Reserve & 64 & 550 \\
Joseph Grant County Park & 64 & 650 \\
Joseph Grant County Park & 68 & 750 \\
Joseph Grant County Park & 61 & 850 \\
Lick Observatory & 39 & 950 \\
Lick Observatory & 64 & 1050 \\
Lick Observatory &
\end{tabular}

Note. Data collection sites of oak samples with corresponding elevation and total number of individual specimens.

Vegetation assessments recorded specimens' DBH, canopy cover, and height class. Height class refers to the category of average plant height at the time of observation. Examples of height intervals for average height trees are $1 \leq 1 / 2 \mathrm{~m}, 5=5-10 \mathrm{~m}, 10 \geq 50$. Shrub cover and associated tree species were estimated with a Rapid Assessment/Releve (CNPS, 2018). Tree coordinates were recorded with Global Positioning System (GPS) units. GPS measurements were accurate to within 3 meters. 
From March 2019 to May 2019, standing lepidopteran herbivory rates and oak community characteristics were recorded for each sampling site along the elevation gradient. Standing lepidopteran herbivory recorded leaf damage from Nymphalidae foliar feeders such as Adelpha californica larvae (Figure 4).
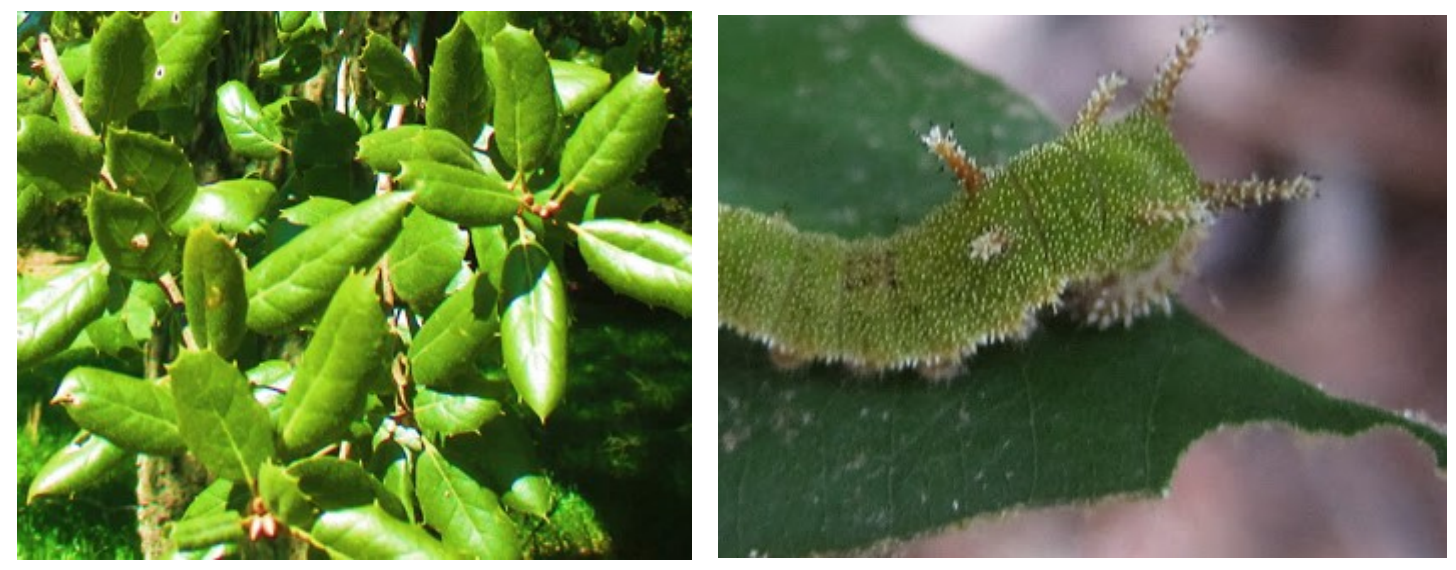

Figure 4. Target species and insect feeding pattern in herbivory surveys. Left-hand image shows coast live oak leaves and Adelpha californica larvae are target specimens in surveys. Right-hand image shows common marginal leaf feeding pattern. Right-hand image adapted from "Butterflies and Moths of North America," by Metalmark Web \& Data, 2019.

The specific herbivory scoring criteria were guided by protocols from Rasmann et al. (2014) and Leckey et al. (2014) and used these metrics:

- the average actual leaf area removed;

- percent leaf area removed;

- number of discreet feeding damage marks per leaf;

- foliar feeding type.

As part of the standing herbivory survey, two lower branches of each oak specimen with at least 10 leaves were surveyed for feeding damage (de Sassi et al., 2012). Leaf damage 
was measured through a square-centimeter grid. Each search was at least one minute for consistency in effort (Leckey et al., 2014).

To determine the elevational difference in foliar defense concentrations, leaf samples from the oak sampling site were collected and analyzed for their phenolic compound concentrations. The analyzed phenolic compounds were kaemphferol, quercetin, gallic acid, ellagic acid. These phenolic compounds are related to defense responses in coast live oaks. Oak phenolic compounds can act as leaves' defensive coloring for camouflage, insect deterrents, and antibacterial protection (Voelckel \& Jander, 2014). Leaf samples were 5 grams in fresh weight. Samples were sent to Brookside Laboratories in New Brennan, Ohio. The laboratory used liquid chromatography (LC-MS/MS) to test the $\mathrm{mg} / \mathrm{kg}$ phenolic compound concentrations of quercetin and kaempherol. LC-MS/MS uses liquid chromatography with highly sensitive and selective mass analysis capability of triple quadrupole mass spectrometry (Voelckel \& Jander, 2014). High performance liquid chromatography (HPLC) was used to test the phenolic compound concentration of gallic and ellagic acid. HPLC separates the phenolic compounds by dissolving the sample in suitable solvents (Voelckel \& Jander, 2014).

Mean annual temperatures and historical weather data was collected from online weather station archives. Weather stations were located in Lick Observatory, Blue Oak Ranch Reserve and Cañada de los Osos Ecological Reserve.

\section{Data Analysis}

All statistical analysis was conducted using IBM ${ }^{\circledR}$ SPSS ${ }^{\circledR}$ Statistics Version 25 . The following analyses tested the predictions of Resource Availability Hypothesis. Mean 
annual temperature was tested to determine temperature's correlation with each sampling site's elevation. Spearman's rank order correlation was used to assess whether a relationship existed between mean annual temperature and elevation. The $r_{s}$ value in Spearman's correlation refers to the correlation coefficient for variables that were converted into ranked scores.

Herbivory rates were represented by the percentages of leaf area removed from each specimen at each sampling site. Herbivory rates at each site were compared to assess a significant difference per elevation. A Kolmogorov-Smirnov normality test found herbivory rates were not normally distributed. As a result, a Kruskal-Wallis H-test was conducted. The Kruskall-Wallis H-test is a rank-based nonparametric test to assess if herbivory rates were significantly different at each elevation. Since variables were not normally distributed, a Spearman's rank-order correlation was used to assess relationships between lepidopteran herbivory rates and elevation. The mean annual temperatures and the corresponding herbivory rates were compared to assess a significant temperature difference between elevations. A Kolmogorov-Smirnov normality test determined herbivory rates were not normally distributed; therefore, a Kruskal-Wallis $\mathrm{H}$ test was used. Dunn-Bonferroni's post hoc tests identified the significant difference between pairs of mean annual temperatures. To address variables' non-normal distribution, a Spearman's rank-order correlation measured the relationship between lepidopteran herbivory rates and mean annual temperature.

Phenolic concentrations were mean concentrations of kaemphferol, quercetin, gallic acid and ellagic acid. A relationship between mean kaemphferol concentrations and 
elevation was determined using the Spearman's rank order-correlation. A one-way analysis of variance (ANOVA) compared the quercetin levels at different elevations, as these data were normal. One-way ANOVA tests also determined the significant difference of gallic acid and ellagic concentrations per elevation.

\section{Results}

A total of 502 oak specimens were sampled at elevations from $350 \mathrm{~m}$ to $1050 \mathrm{~m}$ at all sites (Table 3). Mt. Hamilton has an elevational temperature gradient of approximately $4^{\circ} \mathrm{C}$, a suitable proxy (Rasmann et al., 2018) for climate variability as predicted in Santa Clara County climate change scenarios (Cal-Adapt, 2019; Langridge, 2018). The following results describe the analyses of the Resource Availability Hypothesis (RAH) predictions.

Table 3

Oak Specimens and Temperature Per Elevation

\begin{tabular}{lccc}
\hline $\begin{array}{c}\text { Elevation } \\
(\mathrm{m})\end{array}$ & $\begin{array}{c}\text { Number of Oak specimens per } \\
\text { elevation }\end{array}$ & $\begin{array}{c}\text { Mean Annual } \\
\text { Temperature } \\
\left(\mathrm{C}^{\circ}\right)\end{array}$ & $\begin{array}{c}\text { Standard Error } \\
\text { for Leaf Area } \\
\text { Loss (SE) }\end{array}$ \\
\hline 350 & 65 & 14.58 & 0.882 \\
450 & 76 & 14.33 & 0.815 \\
550 & 64 & 13.11 & 0.889 \\
650 & 64 & 13.92 & 0.889 \\
750 & 68 & 12.67 & 0.862 \\
850 & 61 & 13.66 & 0.91 \\
950 & 39 & 10.8 & 1.138 \\
1050 & 64 & 7.23 & 0.882 \\
\hline
\end{tabular}

Note. Number of oaks sampled, temperature, and standard error for leaf area loss per elevation. 
Mean annual temperature was strongly and inversely correlated to elevation $\left(\mathrm{r}_{\mathrm{s}}=-0.90, \mathrm{n}=502, \mathrm{p}<0.001\right.$; Figure 5), demonstrating an expected RAH relationship.

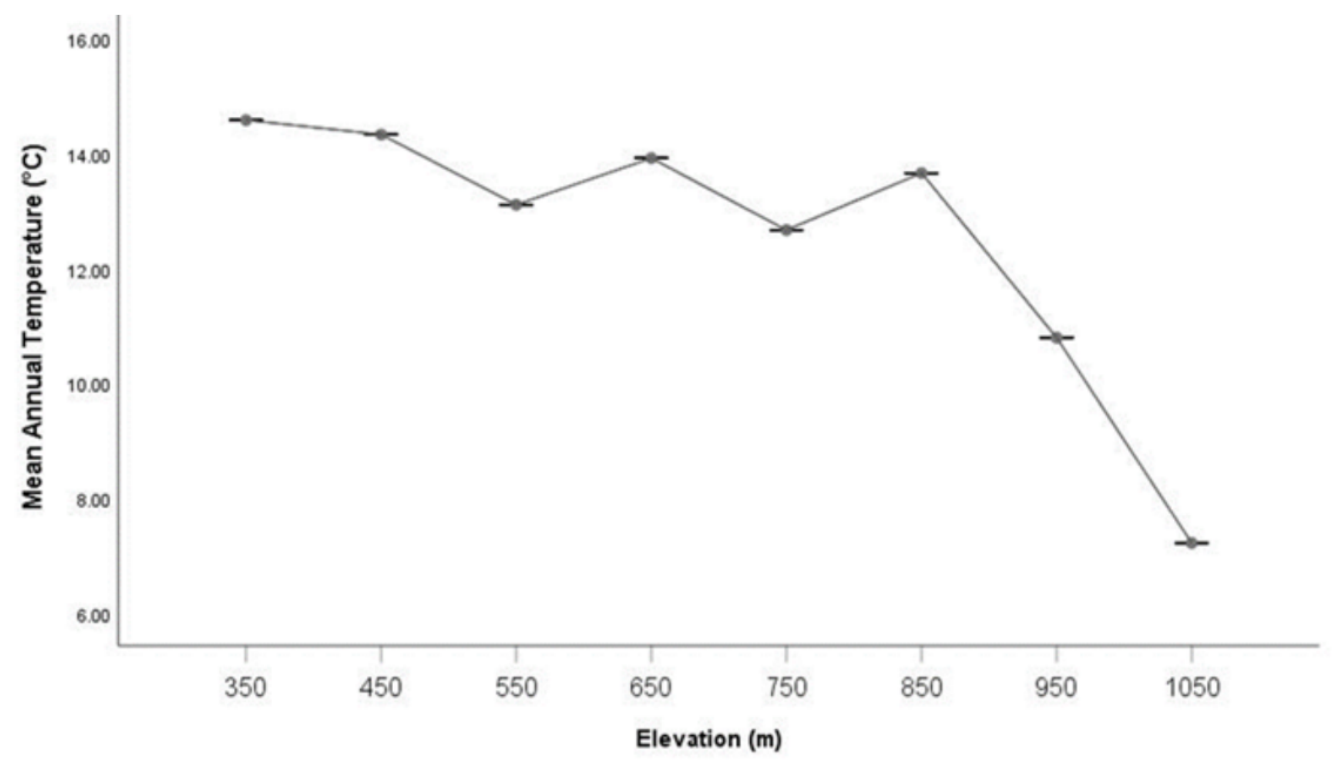

Figure 5. Relationship between mean annual temperature and elevation interval. Error bars represent standard errors (mean $\pm \mathrm{SE}$ ).

Herbivory rates, as measured by percent of leaf area removed, varied greatly between elevation $(H(2)=227.243, p<0.001$; Figure 6$)$, which was a proxy for temperature. There was a weak positive relationship between area removed and elevation $\left(\mathrm{r}_{\mathrm{s}}=0.388, \mathrm{n}\right.$ $=502, \mathrm{p}<0.001)$. Herbivory was significantly higher in individual trees located at the highest sampled elevations ( $850 \mathrm{~m}, 950 \mathrm{~m}$ and $1050 \mathrm{~m}$ ) (Figure 6). The sites in the highest elevations also had the lowest temperatures. Individual trees in the lower elevations $(350 \mathrm{~m}, 450 \mathrm{~m}$, and $550 \mathrm{~m})$ and higher temperatures had lower rates of leaf area loss (Figure 6). 


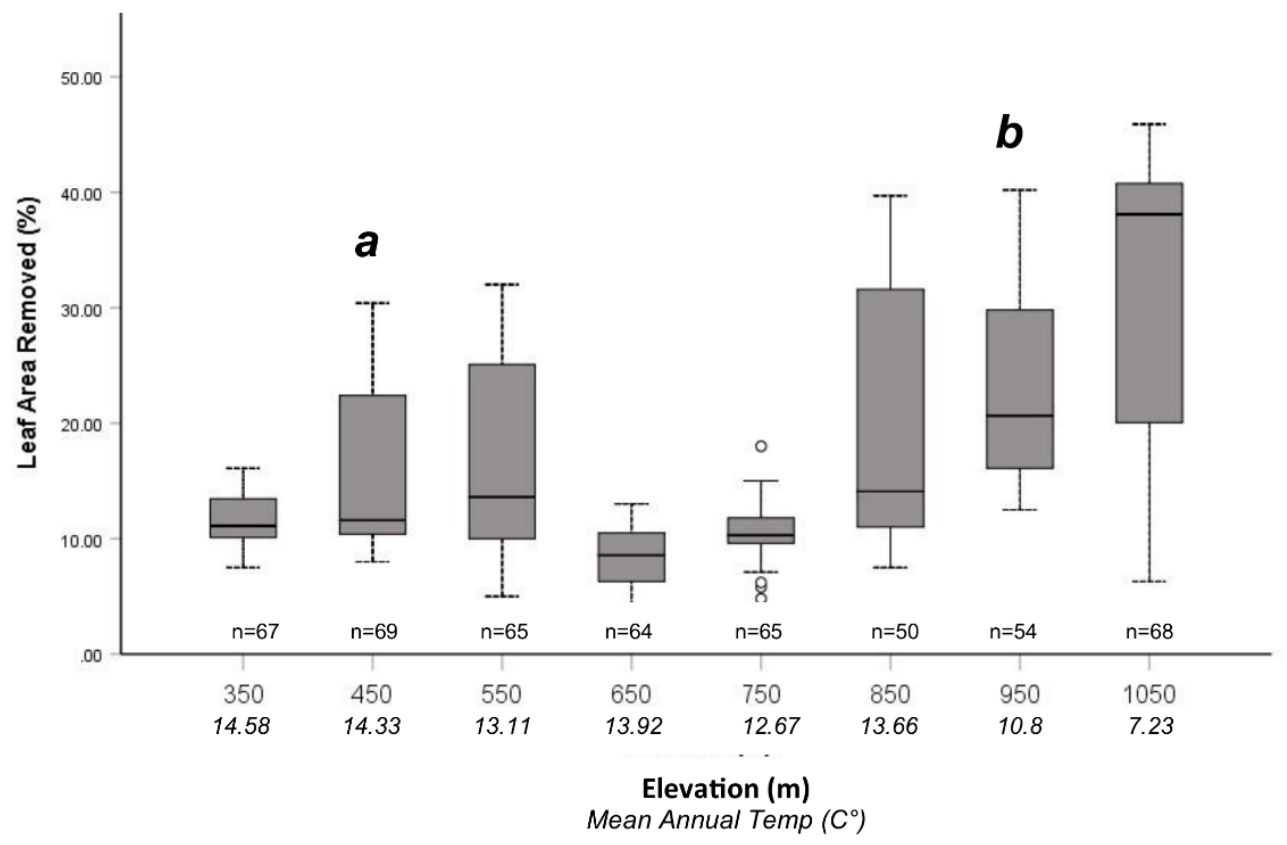

Figure 6. Leaf area loss per elevation and mean annual temperature. The symbols $\boldsymbol{a}$ and $\boldsymbol{b}$ above box plots indicate elevation groups with significantly different herbivory rates. Error bars represent standard errors (mean $\pm \mathrm{SE}$ ).

The percentage of leaf area removed $(n=502)$ significantly differed between different mean annual temperatures $(\mathrm{H}(2)=227.243, \mathrm{p}<0.001$; Figure 6$)$. Leaf area removed was much greater at the mean annual temperatures of higher elevations (950 m and $1050 \mathrm{~m})$ than mean annual temperatures of mid- $(650 \mathrm{~m}$ and $750 \mathrm{~m})$ or low elevations $(350 \mathrm{~m}$ and $450 \mathrm{~m}$ ). Leaf herbivory rates at $450 \mathrm{~m}$ were significantly lower than herbivory rates at mean annual temperatures of mid and high elevations $(650 \mathrm{~m}, 750 \mathrm{~m}$ and $950 \mathrm{~m})$. There was a weak negative relationship between temperature and leaf area removed $\left(r_{\mathrm{s}}=-0.40\right.$, $\mathrm{n}=502, \mathrm{p}<0.001)$.

There were no strong linear relationships with any phenolic compound concentrations and elevation (Table 4). There was no significant mean difference for any phenolic compound concentrations except quercetin (Table 4). There was a significant mean 
difference in quercetin concentrations $(n=24)$ between elevations $(F(7,16)=3.849, p=$ 0.012; Figure 7), with concentrations at $650 \mathrm{~m}$ being greater than those at $450 \mathrm{~m}$ $(\mathrm{p}=0.047)$ or $950 \mathrm{~m}$ elevation $(\mathrm{p}=0.043)$.

Table 4

No Relationships Between Oak Compounds and Elevation

\begin{tabular}{lcccc}
\hline & Quercetin & Kaempherol & Gallic Acid & Ellagic Acid \\
\hline \multirow{2}{*}{ Elevation } & $\mathrm{R}=.030 ;$ & $\mathrm{r}_{\mathrm{s}}=-0.13$, & $\mathrm{R}=.048 ;$ & $\mathrm{R}=.219 ;$ \\
& $\mathrm{p}=0.002$ & $\mathrm{p}<0.001$ & $\mathrm{p}=0.824$ & $\mathrm{p}=0.304$ \\
\hline
\end{tabular}

Note. No strong linear relationships exist between oak phenolic compounds and elevation. $\mathrm{R}, \mathrm{r}_{\mathrm{s}}$, and $\mathrm{p}$-values show the absence of relationships.

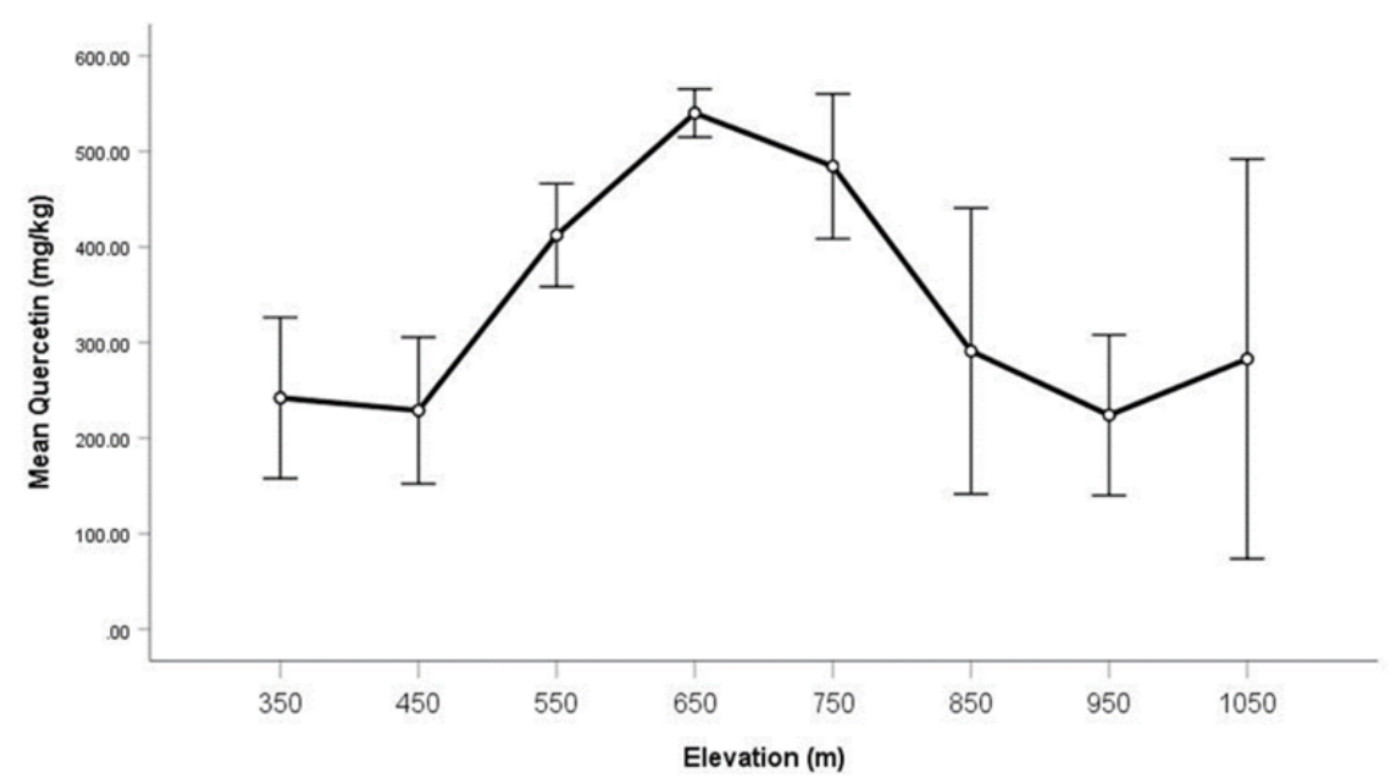

Figure 7. Mean quercetin levels per elevation. Line graph shows significant higher quercetin concentrations in $650 \mathrm{~m}$ elevation than concentrations in $450 \mathrm{~m}$ and $950 \mathrm{~m}$ elevations.

The following results describe the analyses of the Plant-Size Availability Hypothesis predictions. Individual tree diameter (DBH) and herbivory rates were strongly correlated $(\mathrm{r}=0.455 ; \mathrm{n}=502 ; \mathrm{p}<0.001 ;$ Figure 8$)$. Individual plant height and leaf herbivory rates 
were also positively correlated, but the relationship was relatively weak relationship $(\mathrm{r}=0.291 ; \mathrm{n}=502 ; \mathrm{p}<0.001 ;$ Figure 9$)$. There was no relationship between DBH at each elevation for any phenolic concentrations (Table 5). Table 5 also shows no linear relationships between phenolic concentrations and plant height.

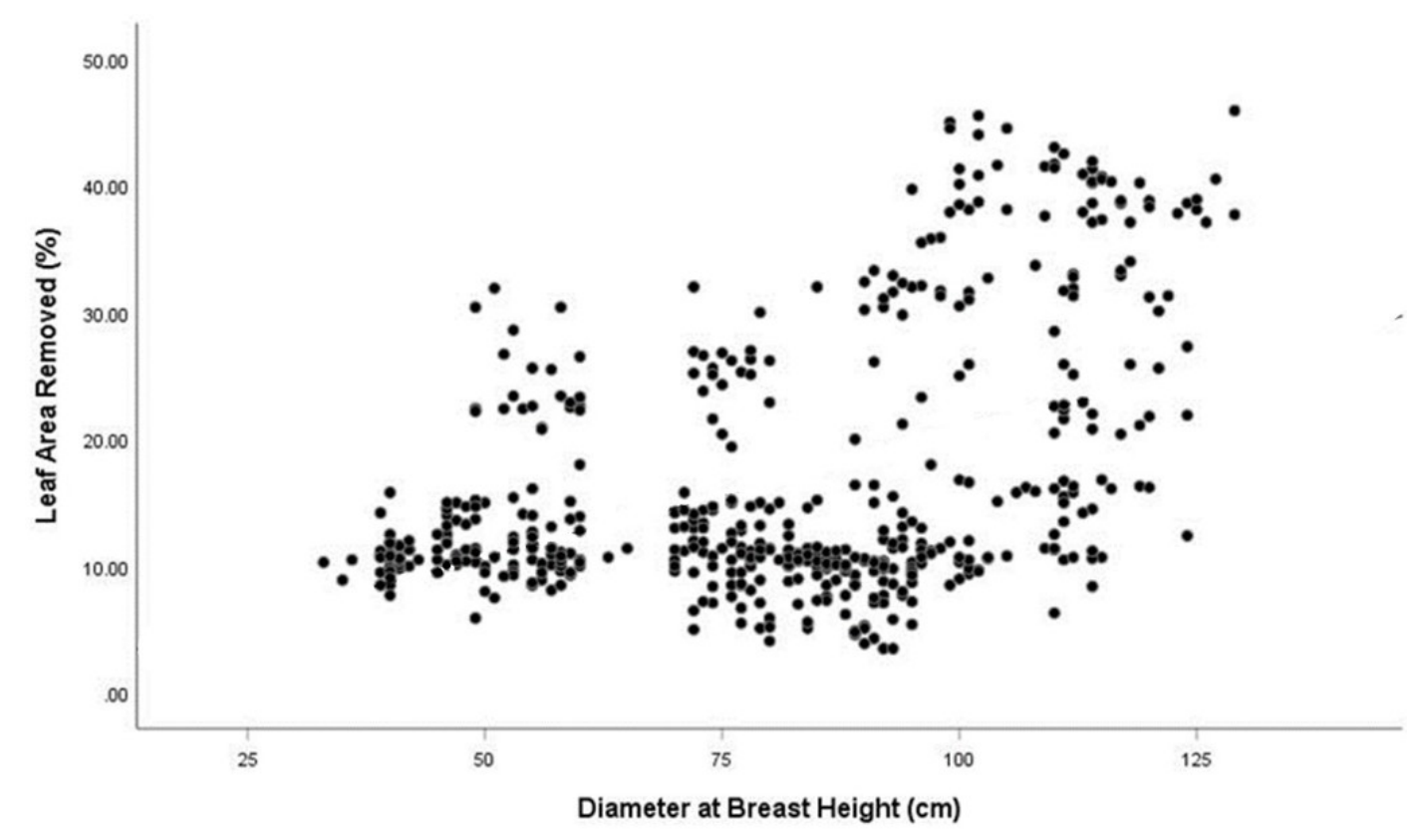

Figure 8. Individual oak diameter (DBH) versus leaf area removed. $\mathrm{n}=502$.

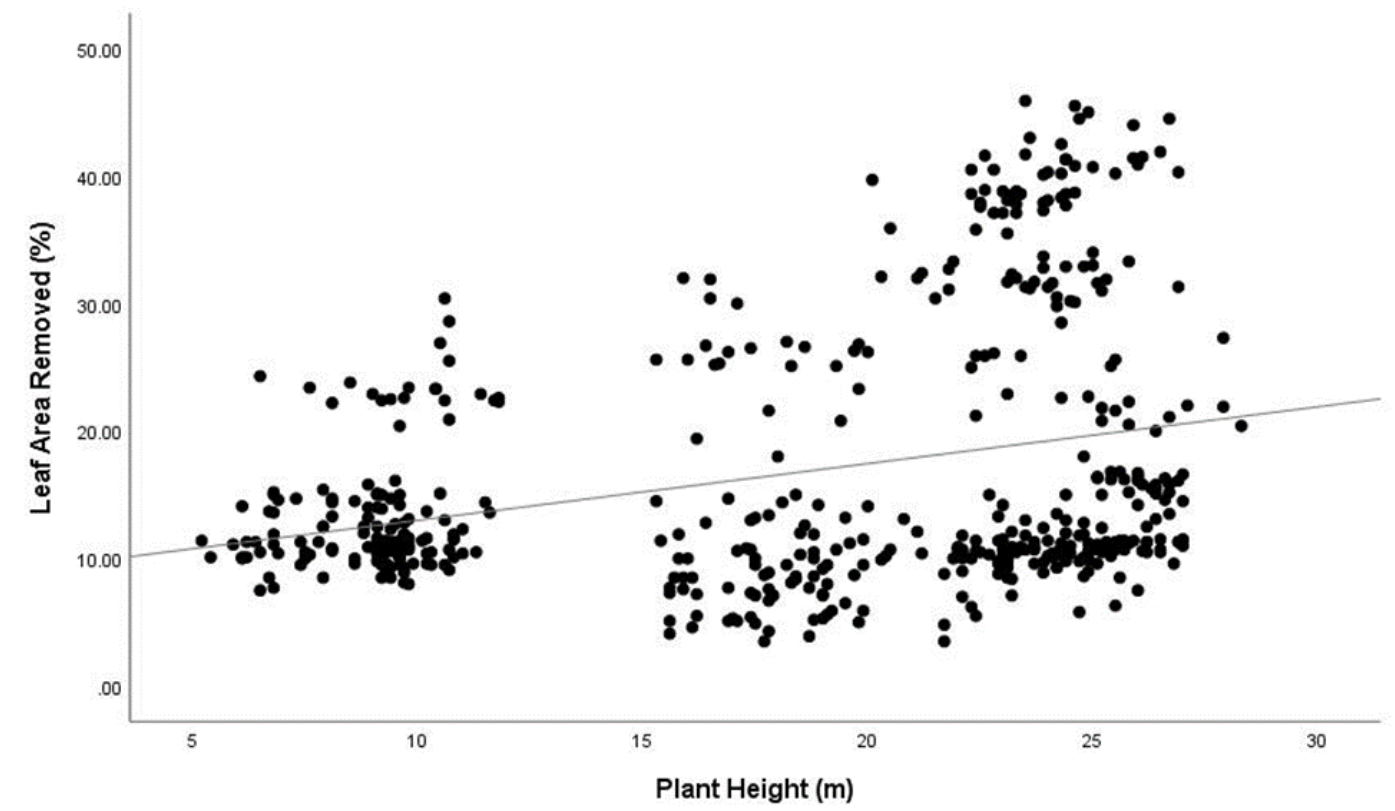

Figure 9. Individual oak height versus leaf area removed. $\mathrm{n}=502$. 
Table 5

No Relationships Between Oak Compounds, Diameter and Height

\begin{tabular}{lllll}
\hline & Quercetin & Kaempherol & Gallic Acid & Ellagic Acid \\
\hline $\begin{array}{l}\text { Oak Diameter } \\
\text { (DBH) }\end{array}$ & $\mathrm{R}=0.067 ;$ & $\mathrm{r}=-0.13$, & $\mathrm{R}=.230$ & $\mathrm{R}=.07$ \\
& $\mathrm{p}=.754$ & $\mathrm{p}=0.550$ & $\mathrm{p}=.288$ & $\mathrm{p}=.746$ \\
$\begin{array}{l}\text { Oak Height } \\
(\mathrm{m})\end{array}$ & $\mathrm{R}=0.183 ;$ & $\mathrm{r}=-.12 ;$ & $\mathrm{R}=.241$ & $\mathrm{R}=.086$ \\
& $\mathrm{p}=0.392$. & $\mathrm{p}=0.570$ & $\mathrm{p}=.256$ & $\mathrm{p}=.690$ \\
\hline
\end{tabular}

Note. No strong linear relationships between oak phenolic compounds, diameter and height. $\mathrm{R}, \mathrm{r}_{\mathrm{s}}$, and $\mathrm{p}$-values show the absence of relationships.

\section{Discussion}

This study examined the relationship between temperature and oak herbivory rates in Santa Clara County, CA, using elevation as a proxy for climate change conditions. I postulated that elevation would provide a suitable temperature range to test the effects of temperature variability. Results indicated the Mt. Hamilton Range is indeed a good system to perform elevational plant-herbivore research. Numerous studies confirm the use of elevational gradients can successfully infer species' responses to climate change (Boscutti et al., 2018; Moreira et al., 2017; Pfennigwerth et al., 2017). Rasmann et al. (2014) referred to elevational gradients as 'optimal ecological surrogates' for predicting climate-driven dynamics. Elevational studies have multiple advantages that may improve climate change research in Santa Clara County. Elevation gradients incorporate local climatic variation that can identify the mechanisms underlying oak-lepidopteran interactions sensitive to climate change impacts (Abdala-Roberts et al., 2016). Through elevational analysis, researchers can also compare interspecific patterns of insect 
herbivores and plant communities at the same scale and climatic range (Abdala-Roberts et al., 2016; Anstett et al. 2016; Moreira et al., 2017, Pfennigwerth et al., 2017).

Moreover, fieldwork along natural climatic gradients associated with elevation can assess long term and short-term plant-insect relationships over multiple generations (Johnson \& Pfennigwerth et al., 2017; Rasmann et al., 2011).

Herbivory rates and phenolic compound concentrations were used to compare the validity of two competing hypotheses predicting the effects of climate change on plant herbivory. The Resource Availability Hypothesis (RAH) proposes that multitrophic trends are driven by ecological gradients such as elevation, temperature, and precipitation (Rasmann et al., 2014; Voelckel \& Jander, 2014). In contrast, the Plant-Size Apparency Hypothesis suggests that a plant will invest morphological defenses such as larger plant growth to increase visibility, dispersal rates and fitness. (Feeny, 1976; Schlinkert et al., 2012;).

Consistent with previous research, this study in Santa Clara County confirmed mean annual temperature was strongly related to both elevation and herbivory rates. This association of temperature with elevation and herbivory suggest elevation may substitute temperature to potentially predict climate-driven impacts in Santa Clara County. Future surveys in other systems of Santa Clara County should test and confirm elevational temperature relationships to ensure an elevational framework is appropriate.

The Resource Availability Hypothesis (RAH) already predicts that rates of insect herbivory, upsurges and species richness will be higher in lower elevations than at higher elevations. (Abdala-Roberts et al., 2016; Anstett et al., 2016; Hahn \& Maron, 2016; 
Pearse, 2011). Contrary to these predictions, this study in the Mt. Hamilton Range found herbivory was significantly greater in the highest sampled elevations compared to lower elevations. Previous elevational studies have also found herbivory patterns to be variable with opposing trends and nonlinear responses (Adams et al., 2011; Zhang, Adams et al., 2011; Pellissier et al., 2012). An analysis of forest herbivores along 24 elevation gradients in Europe confirm an inconsistent effect of elevation and variable herbivory rates among four sampled tree species (Pellissier et al., 2012). Moreover, responses from different insect herbivores such as generalist herbivores, leaf chewers, miners, and sap feeders contradicted RAH expectations (Pellissier et al., 2012)

Galmán et al. (2018) suggest insect herbivory rates were dependent on host-plants' growth form and leaf habit. Their results showed no herbivory trends with non-woody species and evergreen woody species along elevational gradients (Galmán et al., 2018). Herbivory increased with deciduous woody species at lower elevations.

RAH posits that plant defense traits and defensive chemistry will change with climate stress and with other varying elevational conditions (Galmán et al., 2018; Rasmann et al., 2014). At lower elevations, plant chemical defenses include foliar defensive compounds such as secondary metabolites, induced defenses, direct and indirect defenses (Defosezz et al., 2018; Voelckel \& Jander, 2014). High elevation plants resist with morphological resource allocation strategies (Copolovici et al., 2017; Leckey et al., 2014). This study in Santa Clara County was largely inconsistent with expected plant defense patterns in the Resource Availability Hypothesis. Three phenolic compounds showed no differences in concentration with elevation in the Mt. Hamilton Range. A fourth compound, quercetin, 
showed highest concentrations at mid-elevations and lower concentrations at both low and high elevations. Quercetin is an anti-herbivore plant chemical than can be toxic to herbivores and increase their mortality (Voelckel \& Jander, 2014). When consumed by generalist herbivores, quercetin can reduce larval masses (Bale et al., 2002). In addition, quercetin in Pinus sp. can inhibit the development of a gypsy moths, Lymantria dispar, while, studies on peanuts showed quercetin increased mortality rates of tobacco army worms (Spodoptera litura) (Bale et al., 2002).

Recent work in elevational plant-insect studies contradict or partially refute the classical expectations of the Resource Availability Hypothesis. Descombes et al. (2017) and Callis-Duehl et al. (2017) confirm physical and chemical defensive traits were not consistently correlated with elevation. Researchers explain that plant defense patterns may change with the level of ecological organization examined (Callis- Duehl et al., 2017; Descombes et al., 2017). With analyses of singular plant-herbivore interactions, Callis-Duehl et al. (2017) found chemical defensive traits and elevations showed nonlinear relationships. However, in community-level studies, chemical defensive traits declined with increasing elevation (Callis Duehl et al., 2017). Similarly, communityweighted analyses from Descombes et al. (2017) reported increased concentrations of plant palatability chemicals at higher elevations. At the individual species level, there was no effect of elevation on plant palatability chemicals (Descombes et al., 2017). Rasmann et al. (2014) assert the expression of chemical defenses may be contingent on both climatic factors and elevational herbivory. Severe climate, drought (Gutbrodt et al., 2011), and delayed snowmelt might inhibit phenolic concentrations (Torp, Witzell, 
Baxter, \& Olofsson, 2010), secondary metabolism (Jactel et al., 2012), and plant palatability traits (Wright et al., 2007).

Herbivory rates in this study align more closely with predictions in the Plant-Size Apparency Hypothesis. This hypothesis predicts larger plant size may lead to increased visibility, plant palatability, high vigor and lower plant resistance than small plants (Schlinkert et al., 2012). Indeed, this study found a positive relationship between DBH, although a weaker relationship with height and no association with any phenolic compounds. De Sassi, Lewis, \& Tylianaki (2012) found defoliation of woody species and associated insect species richness increased with taller specimens. Although other studies indicate plant height may be significant predictor for leaf area loss, this thesis work found DBH to be a more important indicator.

Understanding and predicting the impacts of climate change in Santa Clara County oak woodlands offers management challenges and research opportunities. Elevational surveys are potentially effective methods to monitor and predict the impacts of climate change on oak woodlands' species ranges (Chen, Flint, \& Seybold, 2011; Colwell, Brehm, Cardelús, Gilman, \& Longino, 2008), species traits (Franks, Weber, \& Aitken, 2013; Moreira et al., 2017), and multitrophic relationships (Moreira et al., 2017). By monitoring how insect herbivory and plant defense along elevational gradients change over time in oak woodlands, researchers and managers can understand abiotic drivers in novel climates. For instance, multi-decadal elevational surveys of chemical defenses (i.e. terpenes) observed wild Thymus vulgaris colonized higher elevations and exhibited novel decreases in palatability (Moreira et al., 2017). The new shift in distribution and 
palatability traits are responses to higher elevations that no longer exhibit former freezing conditions (Amiot, Georgé, Brat, \& Alter, 2005; Thompson, Schwind, Paulo, Guimarães, \& Friberg, 2013). Likewise, long term elevational studies in the oligophagous butterfly Aporia crataegi exhibit critical findings for range-shifted herbivores (Moreira et al., 2017). The elevation range of this herbivore of the was historically limited to the distribution range of its host-plants (Moreira et al., 2017). However, temperature increases over the past several decades have reduced larval survival (Moreira et al., 2017). The decrease in larvae was caused by climate-induced changes in population density, phenology and habitat use at low elevations (Moreira et al., 2017). With new climate stressors, the butterfly only feeds on host-plants in the lower $300 \mathrm{~m}$ of its former range (Merrill, et al., 2008; Moreira et al., 2017). As a result, range-shifted insect herbivores may also encounter species mismatches, novel host species and new plant defense levels (Moreira et al., 2017; Rasmann et al., 2014).

Phenological desynchronization, range shifts and species mismatches need to be monitored in oakwood lands. Some studies suggest oaks may respond to novel climate warming and excessive drought with decreased defenses against herbivores (Moreira et al., 2017). If oak ecosystems are met with new insect outbreaks, they may lack the defenses and risk higher mortalities or defoliation (Mizumachi, Mori, Osawa, Akiyama, \& Tokuchi, 2006). Still, further studies are required to understand if oaks may adapt to climate stressors with decreased plant palatability and higher defenses against new herbivore attacks (Mizumachi, 2006). 


\section{Recommendations}

With current and future climate change impacts on Californian oak woodlands, comprehensive research and progressive open space management is vital (Bedsworth \& Hanak, 2013; Moore, Seavy, \& Gerhart, 2013). Vegetation biologists and resource managers can use elevational plant-herbivore evaluations in concert with other plantinsect frameworks to monitor and predict ecological responses to climate change (Pellisier et al., 2014). Results from elevational surveys can improve multiple aspects of oak woodland management. These aspects include a) restoration planning (AbdalaRoberts et al., 2016; Pearse \& Hipp, 2012) b) the management of local extinctions and novel recolonizations (Defosezz et al., 2018) c) selection of areas for preserve acquisition (Boscutti et al., 2018), and d) the management of new disturbance regimes in current and future climate change scenarios (Rasmann et al., 2014). In turn, managers may be more equipped to understand how climate-related disturbances may impact oaks and dependent herbivores' life histories (Moreira, Petry, Mooney, Rasmann \& Abdala-Roberts, 2018). In addition, elevational assessments of potential climate-related changes to disturbance regimes can greatly improve managers' abilities to adaptively manage oak woodlands ecological functioning and critical ecosystem services (Agne et al., 2018).

\section{Future Research}

The method design, number of target species, and duration of this study were limited by budget and time constraints. Subsequent field surveys using alternate hypotheses in combination with an elevational framework may provide more information. More surveys of Mt. Hamilton's oak-lepidopteran relationships may provide a more robust 
baseline and elevational framework for predicting patterns of climate change impacts (Pfennigwerth et al., 2017; Moreira et al., 2018). Ideally, elevational analyses in Santa Clara County may be more substantive when researchers examine multiple oaklepidopteran relationships across several elevation gradients over two or more years. Long-term studies can better examine the association between elevational herbivory and other abiotic and climatic variabilities such as precipitation, soil characteristics and herbivory (Galmán et al., 2018).

This study was limited by restricting phenolic compound data collection to field surveys. To better understand the relationship between elevation, herbivore pressure and plant defenses, researchers should incorporate common garden experiments (Casner et al., 2014; Rasmann et al., 2014). Researchers could plant corresponding gardens in the same elevation as their native field sites (Rasmann et al., 2014). These garden experiments would be planted with the same target species in field elevational surveys. Herbivory would be observed in both native field sites and common gardens (Casner et al., 2014; Rasmann et al., 2014). Comprehensive and robust elevational studies on multitrophic responses to climate change will be essential to the effective preservation of oak woodlands. 


\section{Literature Cited}

Abdala-Roberts, L., Rasmann, S., Berny-Mier, J., Terán, F., Glauser, G., \& Moreira, X. (2016). Biotic and abiotic factors associated with altitudinal variation in plant traits and herbivory in a dominant oak species. American Journal of Botany, 103, 20702078. doi:10.3732/ajb.1600310

Adams, J., Zhao, D., \& Zhang, Y. (2011). Does insect folivory vary with latitude among temperate deciduous forests? Ecology Restoration, 26, 377-383. doi:10.1007/s11284010-0792-1

Agne, M. C., Beedlow, P. A., Shaw, D. C., Woodru, D., Lee, H. Cline, S., \& Comeleo, R. (2017). Interactions of predominant insects and diseases with climate change in Douglas-fir forests of western Oregon and Washington, U.S.A. Forest Ecology and Management, 409, 317-332. doi: 10.1016/j.foreco.2017.11.004

Alba, C., Bowers, M., \& Hufbauer, R. (2012). Combining optimal defense theory and the evolutionary dilemma model to define predictions regarding plant invasion. Ecology, 93, 1912-1921. doi: 10.2307/23225192

Amiot, M. J., Georgé, S., Brat, P., \& Alter, P. (2005). Rapid determination of polyphenols and vitamin $\mathrm{C}$ in plant-derived products. Journal of Agriculture and Food Chemistry, 53, 1370-1373. doi: 10.1021/jf048396b

Anstett, D., Nunes, K., Baskett, C., \& Kotanen, P. (2016). Sources of Controversy Surrounding Latitudinal Patterns in Herbivory and Defense. Trends in Ecology \& Evolution, 31, 789-802. doi: 10.1016/j.tree.2016.07.011

Bale, J., Masters, G., Hodinson, I., Awmack, C., Bezemer, M., Brown, V., . . Whitaker, J. B. (2002). Herbivory in global climate change research: direct effects of rising temperature on insect herbivores. Global Change Biology, 8, 1-16. doi:

10.1046/j.1365-2486.2002.00451.x

Barba, F. J., Nikmaram, N., Roohinejad, S., Khelfa, A., Zhu, Z., \& Koubaa, M. (2016). Bioavailability of Glucosinolates and Their Breakdown Products: Impact of Processing. Frontiers in Nutrition, 3, 24-26. doi: 10.3389/fnut.2016.00024

Kessler, A., Poveda, K., \& Poelman, E. H. (2012). Plant-Induced Responses and Herbivore Population. In P. Barbosa, D. Letourneau \& A. Agrawal (Eds.), Insect Outbreaks Revisited, (pp. 89-112). doi: 10.1002/9781118295205

Barry, S., Bradshaw, B., Breon, T., Congdon, C., Coons, A., Derry, J. Evens, J., ...Williams, J. (2005). An Oak Woodlands Management Plan for Santa Clara County. 
Retrieved from Santa Clara County website:

https://www.sccgov.org/sites/dpd/DocsForms/Documents/CEQA_OaksPlan.pdf

Bedsworth, L. \& Hanak, E. (2013). Climate policy at the local level: Insights from California. Global Environmental Change, 23, 664-677. doi:

10.1016/j.gloenvcha.2013.02.004

Blanckenhorn, W. (2000). The evolution of body size: what keeps organisms small? The Quarterly Review of Biology, 75, 385-407. doi: 10.1086/393620

Boscutti F., Casolo V., Beraldo P., Braidot E., Zancani M., \& Rixen C. (2018). Shrub growth and plant diversity along an elevation gradient: Evidence of indirect effects of climate on alpine ecosystems. Public Library of Science One, 13, 1-15. doi: 10.1371/journal.pone.0196653

Buckley, J., Widmer A., Mescher, M. C., \& De Moraes, C. M. (2019) Variation in growth and defence traits among plant populations at different elevations: Implications for adaptation to climate change. Journal of Ecology. 107, 1-5. doi: 10.1111/13652745.13171

Buschmann, H., Edwards, J., \& Dietz, H. (2005). Variation in growth pattern and response to slug damage among native and invasive provenances of four perennial Brassicaceae species. Journal of Ecology, 93, 322-334. doi: 10.1111/j.13652745.2005.00991.x

Brady and Associates, Inc. Planners and Landscape Architects. Joseph D. Grant and Ed R. Levin County Parks Resource Management Plan. (1996). California: Brady and Associates, Inc. Planners and Landscape Architects. Retrieved from: https://www.sccgov.org/sites/parks/PlansProjects/Documents/Joseph\%20D.\%20Grant \%20and\%20Ed\%20R.\%20Levin/GrantLevinNRMP-LowerRes.pdf

Brooks, C. N. \& Merenlender, A. M. (2001). Determining the Pattern of Oak Woodland Regeneration for a Cleared Watershed in Northwest California: A Necessary First Step for Restoration. Restoration Ecology, 9, 1-12. doi: 10.1046/j.1526100x.2001.009001001.x

Brown, J.W. (2018). Patterns of Lepidoptera herbivory on conifers in the New World. Journal of Asia-Pacific Biodiversity, 11, 1-10. doi: 10.1016/j.japb.2018.01.008

Boscutti, F., Casolo. V., Beraldo, P., Braidot, E., Zancani, M., \& Rixen, C. (2018). Shrub growth and plant diversity along an elevation gradient: Evidence of indirect effects of climate on alpine ecosystems. Journal of Asia-Pacific Biodiversity, 13, 50-61. doi: 10.1371/journal.pone.0196653 
Buckley, J.; Pashalidou, F. G.; Fischer, M. C.; Widmer, A.; Mescher, M. C.; \& De Moraes, C. M. (2019). Divergence in glucosinolate profiles between high and low elevation populations of Arabidopsis helleri correspond to variation in field herbivory and herbivore behavioral preferences. International Journal of Molecular Science, 20, 174-185. doi: 10.3390/ijms20010174

Cal-Adapt. (2019). Annual Averages. Retrieved from http://cal-adapt.org/tools/annualaverages/\#climatevar $=$ tasmax\&scenario $=$ rcp85\&lat $=37.34375 \& \operatorname{lng}=-$ $121.90625 \&$ boundary=locagrid\&units $=$ fahrenheit

Calflora. (2019). Observation Hotline: Quercus Agrifolia. Retrieved from https://www.calflora.org/entry/observ.html\#srch=t\&taxon=Quercus+agrifolia\&cols=b \&inma $=\mathrm{t} \& \mathrm{y}=37.3617 \& \mathrm{x}=-121.7276 \& \mathrm{z}=12 \& 1 \mathrm{wid}=2 \& \mathrm{lcl}=\mathrm{t} \& \mathrm{crnx}=\mathrm{null}$

California Native Plant Society. (2018). CDFW-CNPS (California Native Plant Society) Protocol for the Combined Vegetation Rapid Assessment and Relevé Field Form and Protocol. Retrieved from https://www.cnps.org/plant-science/field-protocolsguidelines

Callis-Duehl, K., Vittoz, P., Defossez, E., \& Rasmann, S. Community-level relaxation of plant defenses against herbivores at high elevation. Plant Ecology, 218, 291-304. doi: $10.1007 /$ s11258-016-0688-4

Cates, R. (1980). Feeding patterns of monophagous, oligophagous, and polyphagous insect herbivores: the effect of resource abundance and plant chemistry. Oecologia, 46, 22-30. doi: 10.1007/BF00346961

Casner, K. L., Forister, M. L., O'brien, J. M., Thorne, J. Waetjen, D., \& Shapiro, A. (2018). Contribution of Urban Expansion and a Changing Climate to Decline of a Butterfly Fauna. Conservation Biology, 28, 773-782. doi: 10.1111/cobi.12241

Chen, Y., Flint, M., Seybold, S. (2011). Coast live oak, Quercus agrifolia, susceptibility and response to goldspotted oak borer, Agrilus auroguttatus, injury in southern California. Forest Ecology and Management, 261, 1852-1865. doi: https://doi.org/10.1016/j.foreco.2011.02.008

Coleman, T., Graves, A., Hoddle, M., Heath, Z., Chen, Y., Flint, M., \& Seyboldf, S. (2011). Forest stand composition and impacts associated with Agrilus auroguttatus Schaeffer (Coleoptera: Buprestidae) and Agrilus coxalis Waterhouse in oak woodlands. Forest Ecology and Management, 276, 104-117. doi: 10.1016/j.foreco.2012.03.011 
Colwell, R. K., Brehm, G., Cardelús, C. L., Gilman, A. C., \& Longino, J. T. (2008). Global warming, elevational range shifts, and lowland biotic attrition in the wet tropics. Science. 322, 258-261. doi: 10.1126/science.1162547

Copolovici, L., Pag, A., Kännastec, A., Bodescu, A., Tomescu, D., Copolovici, D., ... Niinemets, U. (2017). Disproportionate photosynthetic decline and inverse relationship between constitutive and induced volatile emissions upon feeding of Quercus robur leaves by large larvae of gypsy moth (Lymantria dispar). Environmental and Experimental Botany, 138, 184-192. doi: 10.1016/j.envexpbot.2017.03.014

Costello, L., Hagen, B.W. Jones, K.S. (2012). Oaks in the Urban Landscape. Davis, California. California: University of California Agriculture and Natural Resources.

de-Dios-García, J., Manso, R., Calama, R., Mathieu, F., \& Pardos, M. (2018). A new multifactorial approach for studying intra-annual secondary growth dynamics in Mediterranean mixed forests: integrating biotic and abiotic interactions. Canadian Journal of Restoration, 48, 333-344. doi: 10.1139/cjfr-2017-0139

Defossez, E., Pellissier, L., \& Rasmann, S. (2018). The unfolding of plant growth formdefence syndromes along elevation gradients. Ecology Letters, 21, 609-618. doi: 10.1111/ele. 12926

De Long, M., Sundqvist, K., Michael, J., Gundale, R., \& Wardle, D. A. (2015). Effects of elevation and nitrogen and phosphorus fertilization on plant defence compounds in subarctic tundra heath. Ecology, 31, 9-15. doi: 10.1111/1365-2435.12493

Derong, L., Mengshi, X., Jingjing, Z., Zhuohao, L, Baoshan X., \& Xindan L. (2016). An Overview of Plant Phenolic Compounds and Their Importance in Human Nutrition and Management of Type 2 Diabetes. Molecules, 21, 2-19. doi: $10.3390 /$ molecules 21101374

de Sassi, C., Lewis, O., \& Tylianaki, J. (2012). Plant-mediated and nonadditive effects of two global change drivers on an insect herbivore community. Ecology, 93, 18921901. doi: $10.1890 / 11-1839.1$

Descombes, P., Marchon, J., Prader vand, J., Bilat, J., Guisan, A., Rasmann, S. \& Pellissier, L. (2017). Community-level plant palatability increases with elevation as insect herbivore abundance declines. Journal of Ecology, 105, 142-151. doi: $10.1111 / 1365-2745.12664$

Dostálek, T., Rokaya, M.B., \& Münzbergová, Z. (2018). Altitude, habitat type and herbivore damage interact in their effects on plant population dynamics. Public Library of Science One, 13, 121-130. doi: 10.1371/journal.pone.0209149 
Espeset, A. E., Harrison, J. G., Shapiro, A. M., Nice, C. C., Thorne, J. H., Waetjen, D. P., ... Forister, M. L. (2016). Understanding a migratory species in a changing world: climatic effects and demographic declines in the western monarch revealed by four decades of intensive monitoring. Oecologia, 181, 819-830. doi: 10.1007/s00442-016$3600-y$

Feeny, P. (1976). Plant apparency and chemical defense. In J. Wallace \& R. Mansell (Eds.) Biochemical interaction between plants and insects. (1-40). doi: 10.1007/9781-4684-2646-5_1

Franks, S., Weber, J., \& Aitken, S. (2013). Evolutionary and plastic responses to climate change in terrestrial plant populations. Evolutionary Applications, 15, 189-197. doi: 10.1111/eva.12112

Forister, M. L., McCall, A. C., Sanders, N. J., Fordyce, J. A., Thorne, \& O’Brien, J. (2010). Compounded effects of climate change and habitat alteration shift patterns of butterfly diversity. Proceedings of the National Academy of Sciences of the United States of America, 107, 2088-2092. doi:10.1073/pnas.0909686107

Galmán, A., Abdala-Roberts, L., Zhang, S., Berny-Mier, J., Rasmann, S. \& Moreira, X. (2018). A global analysis of elevational gradients in leaf herbivory and its underlying drivers: Effects of plant growth form, leaf habit and climatic correlates. Journal of Ecology, 106, 413-421. doi: 10.1111/1365-2745.12866

Gallou, A., Baillet, Y., Ficetola, G.F., \& Després. L. (2017). Elevational gradient and human effects on butterfly species richness in the French Alps. Ecology and Evolution, 7, 3672-3681. doi: 10.1002/ece3.2803

Gómez-Zurita, J., Juan, C. \& Petitpierre, E. (2000). The evolutionary history of the genus Timarcha (Coleoptera, Chrysomelidae) inferred from mitochondrial COII gene and partial 16S rDNA sequences. Molecular Phylogenetic Evolution. 14, 304-317. doi: 10.1006/mpev. 1999.0712

González-Zurdo, P., Escudero A., Nuñez, R., \& Mediavilla, S. (2016). Losses of leaf area owing to herbivory and early senescence in three tree species along a winter temperature gradient. International Journal of Biometeorology, 60, 1661-1674. doi: 10.1007/s00484-016-1156-5

Grossinger, R. M., Striplen, C. J., Askvold, R. A., Brewster, E., \& Beller. E. B. (2007). Historical landscape ecology of an urbanized California valley: wetlands and woodlands in the Santa Clara Valley. Landscape Ecology, 22, 103-120. 
Gutbrodt, B., Mody, K., \& Dorn, S. (2011). Drought changes plant chemistry and causes contrasting responses in lepidopteran herbivores. Oikos, 120, 1732-1740. doi: 10.1111/j.1600-0706.2011.19558.x

Haavik, L. G., Flint, M. L., Coleman, T. W., Venette, R. C., \& Seybold, S.J. (2015). Goldspotted oak borer effects on tree health and colonization patterns at six newlyestablished sites. Agricultural and Forest Entomology, 17, 146-157. doi: 10.1111/afe. 12090

Hahn, P. \& Maron, J. (2016). A Framework for Predicting Intraspecific Variation in Plant Defense. Trends in Ecology \& Evolution, 31, 646-656. doi: 10.1016/j.tree.2016.05.007

Hardy, M. A., Vreeland, J. K., \& Tietje, W. D. (2013). Vegetation associations of birds wintering in a California oak woodland. Journal of Field Ornithology, 84, 345-354. doi: $10.1111 /$ jofo. 12034

Hemptinne, J., Magro, A., Evans, E., \& Dixon, A. (2012). Body size and the rate of spread of invasive ladybird beetles in North America. Biological Invasions, 14, 595605. doi: 10.1007/s10530-011-0101-0

Jactel, H., Petit, J., Desprez-Loustau, M. L., Delzon, S., Piou, D., Battisti, A., \& Koricheva, J. (2012). Drought effects on damage by forest insects and pathogens: a meta-analysis. Global Change Biology, 18, 267-276. doi: 10.1111/j.13652486.2011.02512.x

Jamieson, M., Trowbridge, A., Raffa, K., \& Lindroth, R. (2012). Consequences of climate warming and altered precipitation patterns for plant-insect and multitrophic interactions. Plant Physiology, 160, 1719-1727. doi: 10.1104/pp.112.206524

Kergunteuil, A., Descombes, P., Glauser, G., Pellissier, L., \& Rasmann, S. (2018). Plant physical and chemical defense variation along elevation gradients: a functional trait based approach. Oecologia, 187, 561-571. doi: 10.1007/s00442-018-4162-y

Kershaw, J. Mark J. Ducey, M. Thomas W. Beers, T. \& Husch. B. (2016). Sampling Designs in Forest Inventories., In Forest Mensuration 5th Edition. (305-360).doi: $10.1002 / 9781118902028$

Kingsolver, J. G. \& Buckley., L. B. (2018). How do phenology, plasticity, and evolution determine the fitness consequences of climate change for montane butterflies? Evolutionary Applications, 11, 1231-1244. doi: 10.1111/eva.12618. doi: 10.1111/eva.12618 
Koptur, S. (1985). Alternative defenses against herbivores in lnga (Fabaceae: Mimosoideae) over an elevational gradient. Ecology, 66, 1639-1650. doi: $10.2307 / 1938026$

Körner, C. (2007). The use of 'altitude' in ecological research. Trends in Ecology and Evolution, 22, 569-574. doi: 10.1016/j.tree.2007.09.006

Körner, C. (2000). Why are there global gradients in species richness? Mountains might hold the answer. Trends in Ecology and Evolution, 15, 513-514. doi: 10.1016/S0169$5347(00) 02004-8$

Langridge, Ruth. (2018). Central Coast Summary Report. California's Fourth Climate Change Assessment (Publication No: SUM-CCCA4-2018-006). Retrieved from https://www.energy.ca.gov/sites/default/files/2019-07/Reg\%20Report-\%20SUMCCCA4-2018-006\%20CentralCoast.pdf

Leckey, E., Smith, D., Nufio, C., \& Fornash, K. (2014). Oak-insect herbivore interactions along a temperature and precipitation gradient. Acta Oecologica, 61, 1-8. doi: 10.1016/j.actao.2014.08.001

Leingärtner, A., Hoiss B., Krauss J., \& Steffan-Dewenter, I. (2014) Combined Effects of Extreme Climatic Events and Elevation on Nutritional Quality and Herbivory of Alpine Plants. Public Library of Science One, 9, 1-9. doi: 10.1371/journal.pone.0093881

Louda, S. \& Rodman, J. (1983). Concentration of glucosinolates in relation to habitat and insect herbivory for the native crucifer Cardamine cordifolia. Biochemical Systematics and Ecology, 11, 199-207. doi: 10.1146/annurev.ento.54.110807.090623

Machuca, M., Ferreira, C, Martinez, J., Santos, M. (2011). Guidelines for Sustainable Management of Degraded Lands: Experiences on Caatinga and Semi-arid Mediterranean. In Wallace, E. Woodlands: Ecology, Management and Conservation. (91-114). UK: Nova Science Publishers, Incorporated.

Metalmark Web and Data. (2019). Butterflies and Moths of North America. Retrieved from https://www.butterfliesandmoths.org/sighting_details/936954

Maizlish, N., English, D., Chan, J., Dervin, K., \& English, P. (2017). Climate Change and Health Profile Report for Santa Clara County. Santa Clara County. Retrieved from https://www.sccgov.org/sites/opa/nr/Documents/HealthElement_20150825_Adopted_ Final.pdf

Mizumachi, E., Mori. A., Akiyama, R., Tokuchi, N., \& Osawa, N. (2012). Variation in herbivory-induced responses within successively flushing Quercus serrata seedlings 
under different nutrient conditions. Journal of Forestry Research, 17, 175-183. doi: $10.1007 / \mathrm{s} 10310-011-0291-4$

Mclaughlin, B. C., Morozumi, C. N., MacKenzie J., Cole, A. \& Gennet, S. (2014). Demography linked to climate change projections in an ecoregional case study: integrating forecasts and field data. Ecosphere, 5, 1-16. doi: 10.1890/ES13-00403.1

Merrill, R. M., Gutiérrez, D., Lewis O. T., Gutiérrez, J., Díez, S. B., \& Wilson, R. J. (2007). Combined effects of climate and biotic interactions on the elevational range of a phytophagous insect. Journal of Animal Ecology, 77, 144-155. doi: $10.1111 / \mathrm{j} .1365-2656.2007 .01303 . \mathrm{x}$

Moore, S. S., N. E. Seavy, \& M. Gerhart. (2013). Scenario planning for climate change adaptation: A guidance for resource managers. Point Blue Conservation Science and California Coastal Conservancy. Retrieved from http://pointblue.org/wpcontent/uploads/2018/06/CCScenarioPlanning_12263_Moore2013.pdf

Moreira, X., Petry, W. K., Mooney, K. A., Rasmann, S. \& Abdala-Roberts, L. (2017). Elevational gradients in plant defences and insect herbivory: recent advances in the field and prospects for future research. Ecography, 41, 1485-1496. doi: 10.1111/ecog.03184

Pardikes, P., Shapiro, Lee, A., \& Forister, M. (2015). Global weather and local butterflies: variable responses to a large-scale climate pattern along an elevational gradient. Ecology, 96, 2891-2901. doi: 10.1890/15-0661.1

Pearse, I. (2011). The role of leaf defensive traits in oaks on the preference and performance of a polyphagous herbivore, Orgyia vetusta. Ecological Entomology, 36, 635-642. doi: 10.1111/j.1365-2311.2011.01308.x

Pearse, I. \& Hipp, A. (2012). Global Patterns of Leaf Defenses in Oak Species. Evolution, 66, 2272-2286. doi: 10.1111/j.1558-5646.2012.01591.x.

Pellissier, L., Fiedler, K., Ndribe1, C., Dubuis, A., Praderv, Guisan, J. A., \& Rasmann, S. (2012). Shifts in species richness, herbivore specialization, and plant resistance along elevation gradients. Ecology and Evolution, 2, 1818-1825. doi: 10.1002/ece3.296

Pellissier, L., Moreira, X., Holger, D., Serrano, M., Salamin, N. van Dam, N., \& Rasmann, S. (2012). The simultaneous inducibility of phytochemicals related to plant direct and indirect defenses against herbivores is stronger at low elevation. Journal of Ecology, 104, 1116-1125. doi: 10.1111/1365-2745.12580 
Pellissier, L., Aurélien, R., Bilat J., \& Rasmann, S. (2014). High elevation Plantago lanceolata plants are less resistant to herbivory than their low elevation conspecifics: is it just temperature? Ecography, 37, 950-959. doi: 10.1111/ecog.00833

Peters, C. B., Schwartz, M. W., \& Lubell, M. N. (2018). Identifying climate risk perceptions, information needs, and barriers to information exchange among public land managers. Science of the Total Environment, 616, 246-254. doi: 10.1016/j.scitotenv.2017.11.015

Pfennigwerth A. A., Bailey J. K., \& Schweitzer J. A. (2017). Trait variation along elevation gradients in a dominant woody shrub is population-specific and driven by plasticity. AoB PLANTS, 9, 1-13. doi: 10.1093/aobpla/plx027

Rasmann, S., Pellissier, L., Emmanuel, D., Jactel, H., \& Kunstler, G. (2014). Climate Change and Species Range Shifts: Climate-driven change in plant-insect interaction along elevation gradients. Functional Ecology, 28, 46-54. doi: 10.1111/13652435.12135

Remmel T. \& Tammaru, T. (2009). Size-dependent predation risk in tree-feeding insects with different colouration strategies: a field experiment. Journal of Animal Ecology, 78, 973-980. doi: 10.1111/j.1365-2656.2009.01566.x

Schauss, M. \& DeWald, J. M. Cañada de los Osos Ecological Reserve Management Plan. (2005). CA: The Resources Agency Department of Fish and Game Central Coast Region. Retrieved from https://www.wildlife.ca.gov/Lands/Planning/Canada-de-losOsos-ER

Schlinkert, H., Westphal, C., Clough, Y., László, Z., Ludwig, M., \& Tscharntke, T. (2015). Plant Size as Determinant of Species Richness of Herbivores, Natural Enemies and Pollinators across 21 Brassicaceae Species. Public Library of Science One, 10, 1-18. doi: 10.1371/journal.pone.0135928

Scott, T., Turner, K.,Washington, C., Corella, K. (2015). Mapping spread of the Goldspotted Oak Borer (Agrilus auroguttatus). General Technical Report. Proceedings of the 7th California Oak Symposium: Managing Oak Woodlands in a Dynamic World. (pp. 308-315). Retrieved from https://www.fs.fed.us/psw/publications/documents/psw_gtr251/psw_gtr251_307.pdf

SFEI: San Francisco Estuary Institute-Aquatic Science Center. (2017). Re-Oaking Silicon Valley: Building Vibrant Cities with Nature. (Publication 825). San Francisco Estuary Institute. Richmond, CA. Retrieved from https://www.sfei.org/documents/re-oakingsilicon-valley 
Shapiro, A. \& Manolis, T. D. Field Guide to Butterflies of the San Francisco Bay and Sacramento Valley Regions. (2007). Berkeley: Regents of the University of California Press.

Speed, J., Austrheim, G., Hester J. A., \& Mysterud, A. (2012). Elevational advance of alpine plant communities is buffered by herbivory. Journal of Vegetation Science, 23, 617-625. doi: 10.1111/j.1654-1103.2012.01391.x

Thompson, J., Schwind, C., Paulo R. Guimarães, Jr., P., \& Friberg, M. (2013) Diversification through multitrait evolution in a coevolving interaction. Proceedings of the National Academy of Sciences of the United States of America, 110, 1148711492. doi: doi.org/10.1073/pnas.1307451110

Tietje, W., Purcell, K. Drill, S. (2005). Oak Woodlands as Wildlife Habitat. In G. Giusti, McCreary, D. Douglas, R. Standiford (Eds.) A Planner's Guide for Oak Woodlands, Second Edition. (pp 15-27). Davis, California. University of California, Division of Agriculture and Natural Resources.

Torp, M., Witzell, J., Baxter, R., \& Olofsson, J. (2010). The effect of snow on plant chemistry and invertebrate herbivory: experimental manipulations along a natural snow gradient. Ecosystems, 13, 741-751. doi: 10.1007/s10021-010-9351-4

Tscharntke, T. and Hawkins, B. (Eds). (2002). Multitrophic Level Interactions. UK: Cambridge University Press.

Voelckel, C. \& Jander, G. (Eds.). (2014). Annual Plant Reviews, Volume 47: Insect-Plant Interactions. (pp. 309-360). doi: 10.1002/9781118829783.ch6

Wright, I. J., Ackerly, D. D., Bongers, F., Harms, K. E., Ibarra-Manriquez, G., MartinezRamos, M., \& Wright, S. J. (2007). Relationships among ecologically important dimensions of plant trait variation in seven neotropical forests. Annals of botany, 99, 1003-1015. doi: 10.1093/aob/mcl066

Zack, S. Chase, M. Geupel G. \& Stralberg. D. (2005). Oak Woodland Bird Conservation Plan: A Strategy for Protecting and Managing Oak Woodland Habitats and Associated Birds in California. (USDA Forest Service General Technical Report PSW-GTR-191). Retrieved from https://www.fs.fed.us/psw/publications/documents/psw_gtr191/psw_gtr191_01740178_zack.pdf

Zehnder, C. B. \& Hunter, M. D. (2008). Effects of nitrogen deposition on the interaction between an aphid and its host-plant. Ecological Entomology, 33, 24-30. doi: 10.1111/j.1365-2311.2007.00945.x 